\title{
Fear Not For Man? Armed conflict and social capital in Mali
}

Thomas CALVO

Emmanuelle LAVALLEE

Mireille RAZANFINDRAKOTO

François ROUBAUD 


\title{
Fear Not For Man?† \\ Armed conflict and social capital in Mali $§$
}

\author{
Thomas Calvo a,*, Emmanuelle Lavallée ${ }^{\mathrm{a}}$, Mireille Razafindrakotob,a François Roubaud $^{\mathrm{b}, \mathrm{a}}$ \\ ${ }^{a}$ DIAL, LEDa, IRD, CNRS, Université Paris-Dauphine, Université PSL, 75016 Paris, France \\ ${ }^{b}$ IRD, 75010 Paris, France
}

\begin{abstract}
This paper studies the effects of armed conflict on social capital in Mali, where a violent conflict has been raging since 2012. We examine the conflict's impacts on associational membership using event location data and unique survey data on governance, peace and security (GPS-SHaSA). We show that, in conflict-exposed areas, adult involvement in associations increases from 7 to 14 percentage points. Instrumental variable and difference-in-differences strategies complementary mitigate reverse causation and omitted variable biases as estimated results remain very consistent. Robust estimations constrained to non-migrants samples also rule out selection into migration. Yet this result, consistent with the argument that armed conflict cultivates social engagement, is not a positive outcome in the case of Mali. The increase is observed solely for family and political associations, which are comparatively inward-looking and act as interest groups. We interpret this finding as a form of withdrawal behind group or community boundaries, an interpretation supported by further analysis of interpersonal trust. This sort of withdrawal may exacerbate ethnic divisions and deepen the conflict.
\end{abstract}

Keywords: Social capital; Conflict; Participation; Trust; Mali

JEL classification: D71, F51, O12, Z13

\footnotetext{
†Title from a 1977 song and album by Fela Kuti who fiercely opposed the Nigerian army.

$\ddagger$ This Working Paper is a pre-print version of T. Calvo, E. Lavallée, M. Razafindrakoto F. Roubaud (2019): "Fear Not For Man? Armed conflict and social capital in Mali". Journal of Comparative Economics, Forthecoming, available online at: https://doi.org/10.1016/j.jce.2019.11.005.

$\S$ We would like to thank Antoine Pietri, Lisa Chauvet, Marion Mercier, Philip Verwimp, Tillman Brück, Delphine Boutin, Siyavash Eslami Loutij, Marin Ferry, Marc Raffinot, Philippe Bocquier, Pedro Vicente and Mathieu Couttenier for their very useful comments. We would also like to thank all participants at the Defense-conflict economics workshop, the 4 th DIAL conference, the 13th HiCN Workshop, the 2017 CSAE conference and the 2017 EPCS conference. We thank the two anonymous referees for their comments from which we benefited a lot.

* Corresponding author.

Email addresses: calvo@dial.prd.fr (Thomas Calvo), emmanuelle.lavallee@dauphine.psl.eu (Emmanuelle Lavallée), razafindrakoto@dial.prd.fr (Mireille Razafindrakoto), roubaud@dial.prd.fr (François Roubaud)
} 


\section{Introduction}

Terrorism and armed conflicts have become a major concern in recent years as they increasingly challenge individual, local and regional development around the globe. In addition to the destruction of physical capital and human losses, these events have adverse short- and long-term repercussions on economic outcomes (Abadie and Gardeazabal, 2003; Collier et al., 2003; Gaibulloev and Sandler, 2009). There is still an open question about the channels through which armed conflicts impact economic development. The role of social capital warrants particular attention in this respect. ${ }^{1}$ Indeed, it can positively influence development outcomes, especially in areas with market failure, weak formal institutions and scarce public goods (Woolcock and Narayan, 2000). Social capital connects individuals, facilitates collective action and plays a substantial role in the provision of public goods in these areas (Putnam et al., 1993; Durlauf and Fafchamps, 2005). A number of studies have highlighted the pro-social effect of armed conflict (Bellows and Miguel, 2006, 2009; Voors et al., 2012; Gilligan et al., 2014) and some of them have explicitly suggested that the prosocial impact of war may explain the documented economic recovery of many post-war societies (Davis and Weinstein, 2002; Brakman et al., 2004; Miguel and Roland, 2011). However, these studies usually consider social capital as unidimensional or uniform, even though it is theoretically depicted as a multifaceted notion. Studies considering different facets of social capital question this optimism (Cassar et al., 2013; Rohner et al., 2013; Grosjean, 2014). These latter results echo theoretical and empirical evidence based on ethnographic and archaeological data. Indeed, inter-group conflict should favour both altruistic behaviours towards one's own group, and exclusionary behaviours against out-groups, also called parochialism (Choi and Bowles, 2007;Bowles, 2009). This paper contributes to this literature. It focuses on participation in associations according to their characteristics in an attempt to unravel the web of social capital and learn more about the repercussions of armed conflict on social cohesion.

Papers addressing the social legacy of conflicts generally use associational membership as a measure of social capital. However, associations are diverse and their functions and objectives highly heterogeneous. Not all associations have the same implications in terms of social interactions. Social capital can penalise non-members (Acemoglu and Robinson, 2008) and "reinforce polarisation between the 'in' group and the 'out' group" (Durlauf and Fafchamps, 2005). "Social capital can be used by certain groups to overtake others, generating between-group inequality and political tension" (ibid.). The substantial role of association density (and networks) in the rise of the Nazi party in the 1930s (Satyanath et al., 2017) is illustrative of the potential negative effects of social capital. Knack and Keefer (1997) and Fidrmuc and Gërxhani (2008) contrast "Olsonian" and "Putnamesque" associations based on the divergent hypotheses of Olson (1982) and Putnam et al. (1993) regarding the relationship between associational activity and growth. Olsonian groups act as special interest groups at the expense of the rest of the society, whereas Putnamesque groups act more for the community at large without any negative externalities (Knack and Keefer, 1997). This Olsonian/Putnamesque distinction can be viewed in relation to the usual differentiation between strong/bonding and weak/bridging ties (Granovetter, 1973). The former are characterised by kinship-based relationships resulting from shared affinities, for instance, among relatives, neighbours or close friends, whereas the latter relate to a wider network. Bridging relationships are needed to prevent exclusion from social interactions

\footnotetext{
${ }^{1}$ Social capital is defined by Bourdieu (1980) as "the entire aggregate of current and potential resources associated with the possession of a durable network".
} 
(Jackson et al., 2012) and are considered as a "source of value-added" (Burt, 2001). If conflict spurs involvement in associations, then the kind of associations concerned matters to be able to interpret the effects on social interactions and cooperation. Some, far from bridging the gap between groups, actually widen it. To the best of our knowledge, the impact of conflict on membership of different types of associations has never been explored, at least not in a comprehensive empirical manner. Our paper contributes to the literature on the effects of social capital and questions its dominant assumption that social capital is a force of good.

The paper draws on the division between Olsonian and Putnamesque groups to develop a typology of associations to address this knowledge gap in the particularly relevant case of Mali. Mali has been at war since 2012. The conflict broke out when a number of armed groups challenged the government's authority. The insurgents were mainly Tuareg rebel groups fighting for the independence of northern Mali and jihadist groups keen to impose Sharia law on the country. Although Mali has seen repeated Tuareg uprisings, ${ }^{2}$ jihadist groups only started thriving in the late 2000s driven by growing insecurity and central government withdrawal from the Sahelian regions (Julien, 2011). ${ }^{3}$ In January 2012, the jihadists together with the Tuaregs launched their first attacks on military positions in the north. After three months of intense fighting, the major cities of the north, including Timbuktu, Gao and Kidal, were under the insurgents' yoke. The National Movement for the Liberation of Azawad (MNLA), which was supported by Ansar Dine (supported by Al Qaeda in Islamic Maghreb and the Movement for Oneness and Jihad in West Africa), declared the north independent and imposed Islamic law. ${ }^{4}$ Meanwhile, a military coup toppled President Amadou Toumani Touré held responsible for the crisis. As jihadist groups started moving south, France launched Operation Serval under the UN flag and sent troops to stop their progress. By the end of January 2013, most cities had been taken back. Although two peace agreements were signed in 2014 and 2015 (in Ouagadougou and Algiers: Government of Mali, 2015), jihadist groups continue their attacks and political instability has spawned the emergence of new insurgent groups with ethnic and community demands. To date, the conflict has claimed thousands of lives and displaced hundreds of thousands. Although the conflict is essentially rooted in the northern and central part of Mali, it has spread throughout the country. Attacks have even taken place on the Ivoirian border on the southern edge of the country.

Civic engagement plays a key role in Mali. It is recognised as central to local governance, acting as a local intermediary and much-needed counterpart to weak public institutions. Civic engagement mainly takes the form of substantial involvement in community life, especially in local development associations (Kuepie and Sougane, 2014; Chauvet et al., 2015). The most recent Afrobarometer data (2017) report that two-thirds of adults in Mali attend community meetings. The Indices of Social Development (ISD, 2010) show Malian civic engagement to be particularly high compared with other African countries. Indeed, the latest available data rank Mali among the top 15 to 30 countries consistently above the continental mean for "civic activism", "clubs and associations participation" and "interpersonal safety and trust". In addition to this quantitative evidence, Mali's recent history has shown civil society, and associations in particular, to be central to political transition to a democratic system (Roy, 2005). Mali has even been held up as a regional model (Chauzal, 2007) making the outbreak of violence even more unexpected to the international community. Ethnic groups moreover play a key role in the current crisis (Chauzal and van Damme, 2015).

\footnotetext{
${ }^{2}$ Four major uprisings in 1963, 1991, 2007 and 2012 were all followed by peace agreements.

${ }^{3}$ Galy (2013) presents a full background analysis to understand the Malian war.

${ }^{4}$ The Tuaregs tried to distance themselves from the Islamist radicals (as seen from the MNLA's separation from Ansar Dine just days after their alliance was announced).
} 
Therefore, studying what kind of association is fostered by conflict can shed new light on the current state of social interactions in Mali.

To the best of our knowledge, this is the first time a paper has empirically studied the conflict and social capital nexus in Mali and in a former French colony of Sub-Saharan Africa. ${ }^{5}$ Our study broadens the picture and analysis to take in a different context, where the set of institutional characteristics differs substantially from other previously studied countries (La Porta et al., 1999; Djankov et al., 2003). This case study is, unfortunately, still ongoing. The Malian conflict is in deadlock, and responses to date from national and international authorities have fallen short of the mark (Guichaoua and Pellerin, 2017). Furthermore, the Malian conflict presents a hybrid, albeit insufficiently studied form (mixing political grievances, separatism, criminal activity and terrorism), which appears to be spreading in West Africa and destabilising the region with potential unparalleled national and international demographic repercussions. This analysis can provide deeper insights into the conflict's current repercussions and potentially offer more targeted responses.

We use two sets of data to examine the repercussions of armed conflict on social capital in Mali. First, we compute a local index of armed conflict from the Armed Conflict Location and Event Database (ACLED) project developed by Raleigh et al. (2010). ACLED lists all available newspaper articles, press agency telegrams and non-governmental organisation briefs reporting on conflict-related events since 1997. We merge this local index of armed conflict with unique nationally and regionally representative household surveys conducted by the National Statistics Office (NSO) in 2006, 2014, 2015 and 2016. All these surveys include first-hand modules on governance and democracy issues. The 2014, 2015 and 2016 surveys at the core of our study are repeated harmonised add-on survey modules on governance, peace and security (GPSSHaSA) and are included in the main household survey (Continuous, Modular Household Survey, hereafter EMOP). They provide perfectly comparable data on large samples of individuals. ${ }^{6}$ A highly similar 2006 module is used as a pre-conflict benchmark. We draw on these original governance datasets to analyse the repercussions of the Malian conflict on different types of social capital. The data is also rich enough to be able to address potential endogeneity issues which is another limitation of many analyses.

We find that the conflict has a causal impact on adult involvement in associations, raising participation by 7 to 14 percentage points in exposed areas. The results are driven in particular by growth in participation in inward-looking groups (Olsonian groups), namely family and political associations. These results are robust to a number of robustness checks for reverse causation, omitted variables and selection issues. We rely on two alternative strategies to address reverse causation wherever possible: instrumental variables (IV) and difference-in-differences (DiD) estimations. We interpret these findings as evidence that an increase in associational membership, far from being pro-social, actually forms a veiled withdrawal behind inner group or community frontiers and can therefore spawn exclusion and local tensions. Our interpretation is supported by additional tests showing that interpersonal trust decreases significantly in exposed areas.

The paper is structured as follows. In section 2, we present the related literature and the conceptual framework. In section 3, we describe our data and introduce the empirical model. In section 4, we present our estimation results for associative engagement. Section 5 further investigates the effects of the armed

\footnotetext{
${ }^{5}$ Countries commonly studied in the conflict literature in Africa are Burundi, Kenya, Sierra Leone, Rwanda, Tanzania and Uganda. Some other analyses focus on European countries (e.g. Grosjean, 2014).

${ }^{6}$ Samples include up to 54,000 individuals. Data surveys with large samples representative at regional and even sub-regional level are required to ensure reliable results from an analysis of the impact of armed conflict in certain specific areas of the country. Many sub-national analyses are based on surveys with small samples representative at national level only.
} 
conflict on the types of social capital cultivated. We summarise our findings and conclude in section 6 .

\section{Related literature and conceptual framework}

\subsection{Social capital, associational membership and types of groups}

The notion of social capital can be defined in a number of ways. In this paper, social capital refers to resources generated by structural relations or networks gravitating around an individual. Unlike some analyses, we consider that trust is not a component of social capital per se. We make a clear distinction between trust and social capital. We are aware that trust and social capital are often studied as one. We argue that trust is an attitude that can be a factor (upstream) or a consequence (downstream) of social capital (Woolcock, 1998; Lin, 1999). Indeed, a number of studies posit that trust and social capital are mutually reinforcing (Sønderskov, 2011). Some show that trust builds up people's networks and relations (Narayan and Pritchett, 1999; Haddad and Maluccio, 2003), whereas others find an opposite relationship (Paxton and Ressler, 2017).

We focus on one component of social capital: membership of associations, classified as a formal network as opposed to an individual network, which we define as informal. ${ }^{7}$ The associative sector is heterogeneous with a wide range of associations for which a typology needs to be developed. In keeping with Knack and Keefer (1997) and Fidrmuc and Gërxhani (2008), we make a distinction between Putnamesque groups and Olsonian groups. Olsonian groups act as special interest groups at the expense of the rest of the society, whereas Putnamesque groups act more for the community at large without any negative externalities. In line with Fidrmuc and Gërxhani (2008), educational, sport and art clubs, religious and charitable organisations, and youth groups are considered as Putnamesque groups. On the other side, political associations, trade unions and professional associations are classified as Olsonian groups. Our approach is somewhat different in that our classification focuses on the association's orientation, strategy and promoted values rather than on its sector of intervention. More specifically, we separate out inward-looking (hereafter Olsonian) groups and outward-looking (hereafter Putnamesque) groups. For example, we believe that human rights organisations, which can be classified as political associations, cannot be included in the Olsonian groups. Therefore, in our typology, Putnamesque organisations are open to individuals from different groups/categories. They hence enable individuals to develop their bridging social capital as they constitute an inclusive process. Activities benefit a broad community that extends beyond its members. ${ }^{8}$ Conversely, Olsonian groups are more often based on kinship ties, enabling the development of bonding social capital. Activities benefit solely their members even to the detriment of non-members. ${ }^{9}$ The principle of favouring only their members sets up a barrier and creates an isolation and exclusion process. An increase in participation in these inward-looking (bonding) associations indicates social withdrawal rather than pro-social behaviour. In our typology, we assume that political, family and professional associations are Olsonians. As already mentioned, the inclusion of political associations in this group is questionable. However, in the case of Mali, there is no question since sectarianism and cronyism prevail in political associations in the country (Roy, 2005).

\footnotetext{
${ }^{7}$ A formal network refers to a network that is visible (groups or associations even though they are not necessarily formally declared), whereas individual networks are called informal since they are less visible.

${ }^{8}$ This description ties in with Sønderskov (2011) who points out the particularity of associations that produce public goods. See also Paxton and Ressler (2017) for a description of bridging and bonding associations.

${ }^{9}$ Alesina and Giuliano (2014) show that family ties, as the strongest ties, are negatively linked to growth drivers.
} 
Local development associations are classified as Putnamesque organisations. Religious associations can also be considered as outward-looking, given the specific context of Mali. More than 95\% of the population is Muslim. Malian Islam, which originated from the same Sunni tradition, is characterised by tolerance and syncretism. Over the last two decades, Mali has seen a general wave of re-Islamisation in the country. Islamic associations have been flourishing, but mainly as charitable organisations (Holder and Saint-Lary, 2013). Their main motive is to challenge the central state for its corruption, poor governance and lack of redistributive policies, rather than religion-based violent confrontation.

This distinction between Olsonian/inward-looking and Putnamesque/outward-looking associations sheds new light on what group membership really captures and the interpretation of the so-called pro-social effects of war.

\subsection{Social capital and conflict: a literature review}

Studying the impact of conflict on social capital is of the utmost importance, as it can influence countries' post-war economic, social and political paths. Some studies, as in Voors et al. (2012), explicitly suggest that the "pro-social" impact of war may explain the documented economic recovery of many post-war societies (Davis and Weinstein, 2002; Brakman et al., 2004; Miguel and Roland, 2011). The reasons why war might influence social capital are not well-established, but can be summarised as follows (see Bauer et al., 2016, for an overview). Investing in social capital is part of a household's war-coping strategy. Social capital, in the form of greater cooperation or participation in associations, can act as informal insurance to minimise the adverse repercussions of war and shocks in general (destruction of assets and crops, injury and death) on household welfare (Uphoff and Wijayaratna, 2000). In wartime, social cooperation helps people protect themselves. On this point, community responses such as neighbourhood watch schemes, local vigilante groups, and self-defence forces are documented in civil wars in Liberia and Afghanistan (Sawyer, 2005; Jones and Muñoz, 2010). In addition, studies in psychology suggest that exposure to war steadfastly steers behaviour (Dyregrov et al., 2002) and preferences towards greater participation in the community (Carmil and Breznitz, 1991).

The literature on the impact of armed conflicts on social capital turns up mixed findings. Jennings and Sanchez-Pages (2017) use a theoretical approach to show that, below certain intensity thresholds, conflicts increase social capital in the form of group creation. Yet above these levels, social capital decreases and can end up lower than its peacetime level. The empirical literature's conclusions are dependent on the context and the expression of social capital studied. On the subject of social participation, studies on Sierra Leone, Nepal and Burundi show that violence increases collective action and civic engagement (Bellows and Miguel, 2006, 2009; Voors et al., 2012; Gilligan et al., 2014). In a study on Uganda, Blattman (2009) finds that the impact of civil war is greater for direct participants, particularly abductees and militia members. The former are more involved in local political activities at community level. In a meta-analysis of 16 studies in the areas of economics, anthropology, political science, and psychology, Bauer et al. (2016) use a synthetic index of cooperation to show that the effect of armed conflict on social capital is on average positive and statistically significant, but moderate in magnitude. Yet, this positive interpretation of increased participation is somewhat contradictory with theoretical and empirical evidence based on ethnographic and archaeological data. Indeed, inter-group conflict should favour pro-social behaviours towards one's own group but should simultaneously imply exclusionary behaviours towards out-groups (Choi and Bowles, 2007;Bowles, 2009). The study of collective action in European countries during post-World War II period 
suggests this increased in-group bias (Grosjean, 2014). The increased participation rather evokes the increase of a negative social capital also featured in the rise of the Nazi party (Satyanath et al., 2017).

On the subject of trust, countries affected by slave trading (characterised by violence between ethnic groups) currently form the most distrustful populations in Africa (Nunn and Wantchekon, 2011). A study on Uganda by Rohner et al. (2013), combining Afrobarometer data with ACLED event data, shows that generalised trust is lower for individuals in areas exposed to violent conflicts. Furthermore, a number of studies highlight that the impact of a conflict on trust can vary over time or according to local or individual characteristics. In Uganda, De Luca and Verpoorten (2011, 2015) take the same dataset as Rohner et al. (2013) to show that the conflict had a negative short-term impact on generalised trust and associational membership, but a positive impact on these factors in the longer run. In Tajikistan, Cassar et al. (2013) draw on behavioural experiments and individual surveys to demonstrate that interpersonal trust in ethnically diverse villages is lower in the most exposed areas ten years after the end of the civil war. In their metaanalysis, Bauer et al. (2016) show that the effects of armed conflict on trust are close to zero.

Few studies come to clear conclusions about social interactions, with the exception of Colletta and Cullen (2000) who show that the post-genocide period in Cambodia improved bridging relationships in the village with higher market penetration forces, thereby reducing bonding networks. However, some studies suggest the potential mechanisms through which conflicts increase inward-looking interactions. Some posit that armed conflict can strengthen kinship-based ties due to a stronger ethnic identity (Rohner et al., 2013), increase "kinship-based norms of morality" (Cassar et al., 2013), and elevate egalitarian motivations towards in-group members among children exposed to the conflict (Bauer et al., 2014).

\subsection{Differentiated effects of conflict on social capital}

In some papers (see for instance: Bellows and Miguel, 2006, 2009; Voors et al., 2012), an increase in participation in associations in conflict-affected areas is positively interpreted as pro-social. Conversely, a decrease in participation in associations is presented negatively as social withdrawal. Yet these works say little about what participation in groups really captures. As illustrated in Figure 1, the meaning of these results can change dramatically when the type of association is considered. Exposure to violence might be more conducive to some associations than others. The increase in participation in groups in conflict-affected areas might correspond to an increase in participation in Putnamesque associations. If so, it would be considered as pro-social behaviour enabling increased interaction, cooperation and exchange across groups and would therefore be a driver for the documented post-war economic recovery in affected areas. Conversely, the conflict might be expected to be conducive to participation in Olsonian associations only. Increased participation in inward-looking associations widens the gap between groups as all groups give precedence to their own self-interests. This would lead to greater opposition between groups, and would eventually lock the conflict in a "conflict trap" (Collier et al., 2003).

To further understand the effects of conflict on social capital and participation in associations in particular, we also explore the impact of conflict on interpersonal trust. We consider different components of interpersonal trust: generalised trust, intra-group trust and inter-group trust. As presented in sub-section 2.1 and Figure 1, there is a link between participation in groups and interpersonal trust. Intra-group trust refers to an individual's immediate circle. Here, intra-group trust is captured by trust in relatives and neighbours. Inter-group trust refers to the different out-groups that communities can form. These include other ethnic groups, other region or country groups, and other political affiliation groups. An increase in 
Figure 1: The Violence - Social Capital - Trust nexus

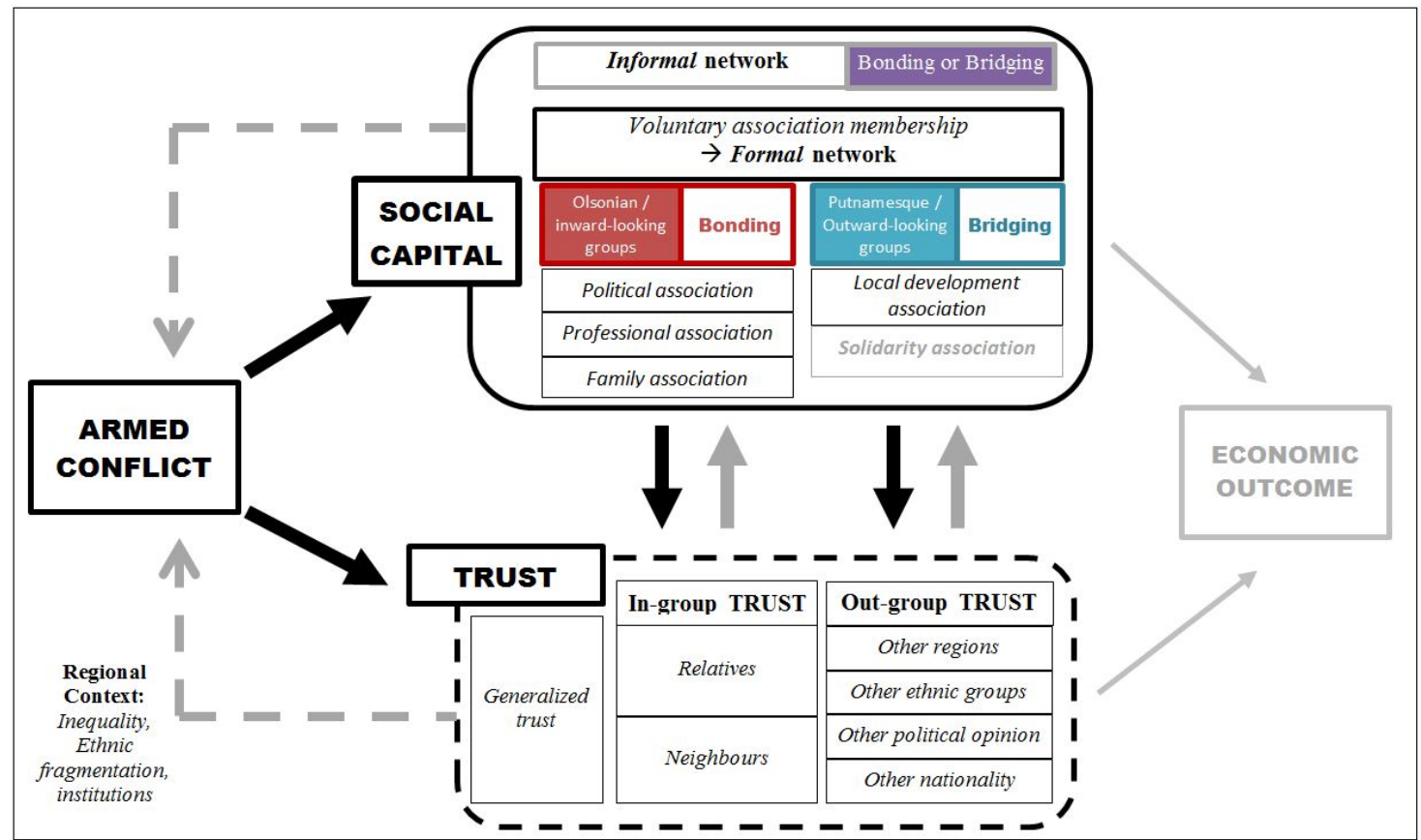

Sources: Authors' elaboration.

generalised trust in conflict-affected areas combined with an increase in participation in associations would point to an overall improvement in social cohesion. Conversely, a decline in inter-group trust in conflictaffected areas combined with a rise in associational membership would reflect the development of bonding rather than bridging social capital.

The following section presents our data and the empirical strategy we use to unravel the web of social capital and learn more about the impacts of armed conflict on social cohesion.

\section{Data and methodology}

\subsection{Data presentation}

Survey data

In this study, we use a unique database: repeated cross-section data from the Governance, Peace and Security (GPS-SHaSA) survey modules. The GPS-SHaSA modules were developed by the African Union Commission as part of a continent-wide initiative named the Strategy for the Harmonization of Statistics in Africa (SHaSA). The methodology for these household survey add-on modules is based on previous experience in African and Latin American countries (Razafindrakoto and Roubaud, 2018).

In Mali, the modules were grafted on to two different household support surveys conducted by the Malian National Statistics Office (NSO) using the same sampling methodology. ${ }^{10}$ The main survey is

\footnotetext{
${ }^{10}$ Households are drawn from a traditional two-stage stratified sample (at regional and urban/rural levels based on the Malian censuses).
} 
the EMOP. It was conducted in 2014, 2015 and 2016 in all Malian regions, excepting Kidal for all three rounds and Timbuktu and Gao in 2014 for obvious security reasons. The complementary survey is the 2006 Short-Form, Integrated Household Survey (ELIM). This latter survey provides a highly reliable point of comparison with the EMOP data and forms a conflict-free benchmark. ${ }^{11}$ Both support surveys include the usual sociodemographic questionnaires and are representative at national and regional level, but the very large available samples also allow for inference at cercle (hereafter, called district), arrondissement (hereafter, called sub-district) and commune levels. ${ }^{12}$

These add-on modules interview people over 18 years old living in Mali. A maximum of three adults per household were interviewed in 2014, 2015 and 2016, ${ }^{13}$ whereas all adults were interviewed in 2006 . For the comparability of estimation, three adults were drawn at random from each household comprising four or more adults in the 2006 sample. The pooled sample from the three post-2012 surveys (2014, 2015 and 2016$)$ provides a main sample of over 43,000 observations, while the 2006 survey database includes 11,670 adults. These modules ask questions about perceptions and experience of governance and insecurity at national and local level, and interpersonal trust and participation in associations. ${ }^{14}$ The following questions are of particular interest here:

- Participation in an association: "Are you an office-bearer or a member of an association?" The binary answer is given for the five following types of association: local, family, religious, professional and political. An aggregated measure of participation in at least one of these five associations is created.

- Trust: "To what extent can most people be trusted?" and "To what extent do you trust: ... - your relatives? - your neighbours? - people from a different ethnic group/race than yours? - people with a different language/dialect than yours? - people with a different political affiliation than yours? - people with a different nationality than yours?". The potential answers are gradient from 1 (not at all) to 4 (very). For the purposes of interpretation, we aggregate the answers into a binary outcome. Both "not at all" and "not much" answers take the value of 0 , while "fairly" and "very much" take the value of 1. It is also important to note that the groups or category of individuals considered for interpersonal trust do not fit exactly within the association types. For instance, trust in relatives is a proxy measure of intra-group trust. Yet, relatives include, here, all members of the extended family who are not necessarily members of inward-looking group embodied by family associations.

Descriptive statistics confirm the importance of participation in groups in Mali (reported in appendix Table A1). In total, $50 \%$ of adults take part in at least one association. This corresponds to $70 \%$ of households with one or more members engaged in at least one association. Bamako, the capital, has the smallest participation rate. Local associations represent the majority of the population, with $35 \%$ of adults belonging to a local association ( $50 \%$ of households report at least one adult member in a local association in 2014 and after). These associations play a substantial role in the local provision of public goods and small

\footnotetext{
${ }^{11}$ The 2006 Tuareg uprising was a minor bout of unrest occurring only in the Kidal region.

${ }^{12}$ Mali counts eight regions plus the capital Bamako (three regions are in the northern part of the country). Each region is divided in cercles, which correspond to districts. Sub-districts and communes are lower administrative level areas, and both correspond to a group of villages. Administrative divisions are mapped in appendix Figure A1.

${ }^{13}$ If there are more than three adults in the sampled household, then three of them are drawn at random to be interviewed.

${ }^{14}$ In the pre-conflict sample (2006), information on participation is observed at household level only. Interpersonal trust was not measured in 2006.
} 
infrastructures (Kuepie and Sougane, 2014). A total of $20 \%$ of adults are members of a family, professional or political association. Family associations play a financial support role for a group of related individuals. Their members can also rely on it for particular events (births, deaths, marriages, etc.). Religious associations account for the fewest citizens. In addition, $70 \%$ of adults say they trust most people. No clear variation can be identified in participation and trust levels over time at first glance. The analysis of how the conflict disrupted the apparently highly pro-social society is thus extremely relevant in Mali.

\section{Conflict data}

The conflict location and event inventory is taken from the ACLED project developed by Raleigh et al. (2010). ACLED is based on a census of all newspaper articles, press agency telegrams and non-governmental organisation briefs reporting conflict-related events in Mali since 1997. In addition to the geolocation of each event, the database provides general information on the groups involved, the reported number of fatalities (undifferentiated by which side they are on), the information source, and a brief summary of the event. We limit the event study to precisely located violent events covering all types of "battles", "remote violence" and "violence against civilians" detailed by the ACLED typology. ${ }^{15}$ "Battles" represent two opposing armed groups and are distinguished by their outcomes as to a change or not in control of a location (no change, or if the non-state actors or government wins). "Remote violence" corresponds to one sided-violence and concerns mainly the use of bombing devices; the physical presence of the perpetrator is not required for this type of event. "Violence against civilians" represents one-sided events that directly target unarmed civilians.

ACLED recorded 529 events prior to 2016, Kidal excluded (758 including Kidal); 464 of these events occurred in 2012 or later. ${ }^{16}$ Figure 2a shows that all eight regions and Bamako have been affected by conflict-induced violence included southern regions: attacks even took place at the Ivoirian border, which is in the southernmost part of the country. Figure $2 \mathrm{~b}$ highlights that the majority of the violent events were led by jihadist groups (half of the recorded violent events outside of Kidal region involved jihadist groups from 2012 to 2015) rather than Tuareg armed groups (16\% of all violent events recorded in Mali, Kidal excluded). ${ }^{17}$ Figure $2 \mathrm{~b}$ illustrates the evolution of the conflict. Violent events skyrocketed in 2012 with the re-emergence of rebel and jihadist activity. Following the French military intervention in 2013, field battles, violence against civilians and remote violence intensified. In 2014, following the Ouagadougou peace agreements and the deployment of the UN Multidimensional Integrated Stabilization Mission in Mali (MINUSMA), violence temporarily abated. However, despite the Algiers peace agreements, there was a fresh upsurge in violence in 2015.

All violent events are aggregated yearly at sub-district level and are merged with the survey data based on the surveyed adults' administrative areas of residence. We use the sub-district level of aggregation rather than the commune level for two reasons. First, communes correspond to very small entities in Mali and geolocation is rarely perfect. The location of violent events at sub-district level makes exposure identification errors marginal. Second, there is substantial variance in commune size between the north and south of the country. The aggregation of events at sub-district level therefore makes for a more reliable

\footnotetext{
${ }^{15}$ Twenty events from 2012 to 2015 were dropped for reasons of imprecise location. Also excluded from the sample are conflict-related non-violent events (strategic troop movements and establishment of headquarters), and riots and protests related to political demands (mainly in Bamako).

${ }^{16}$ In total, 40 events were recorded from 2006 to 2011.

${ }^{17}$ The other events correspond mainly to other violent ethnic related militia rebellions.
} 
comparison between north and south. ${ }^{18}$ We compute a dummy variable that denotes exposure to conflictrelated violence. It takes the value of 1 if individual $i$ lives in a sub-district where violent events took place in the calendar year before the survey. ${ }^{19}$ The focus on violent occurrences rather than on the number of events recorded or number of fatalities is driven by a number of considerations. As acknowledged by Raleigh et al. (2010), violent event intensity measured by the number of fatalities in each location is not reliable information. Where the media does not report a specific number of fatalities in a violent event, ACLED (like other event location databases) assigns default numbers. It is moreover easier to check the number of events than the number of deaths. Lastly, we intuitively assume that measurement errors are larger on the intensive margin than on the extensive margin. ${ }^{20}$ Descriptive statistics presented in appendix Table A1 show that, from 2014 to 2016, the population was exposed on average to less than one violent event per sub-district in the year prior to the survey (at least of the 200 sub-districts surveyed). The annual average number of violent events captured per sub-district between 2014 and 2016 did not exceed 1.7 events (in 2016 for 2006-2015 events). Depending on the survey round and the time window considered, from one-fifth to two-fifths of the sample are exposed to conflict-related violence.

Figure 2: Rebellion, terrorism and conflict-related events in Mali, 1997-2015

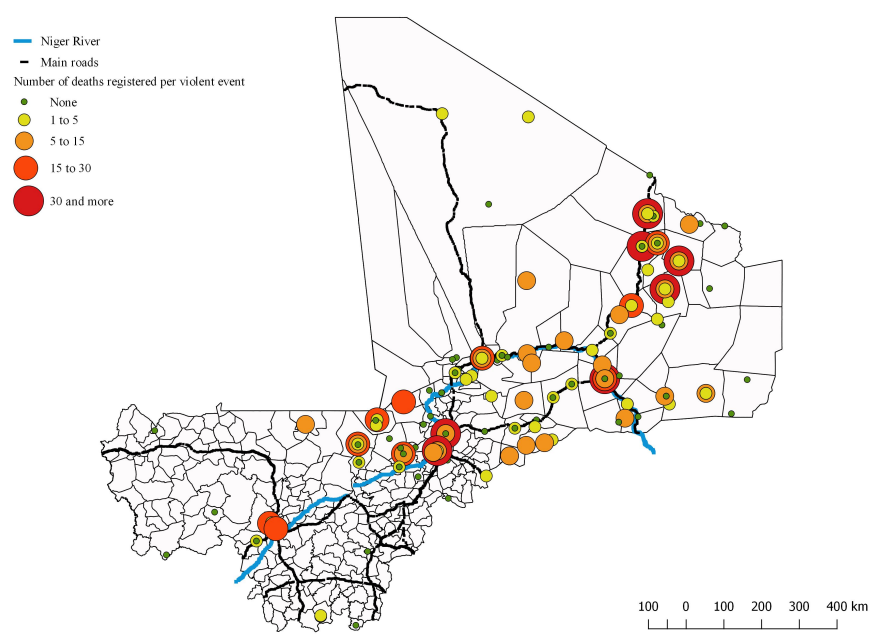

(a) Sub-districts, the Niger River, main roads and violent events (2012-2015)

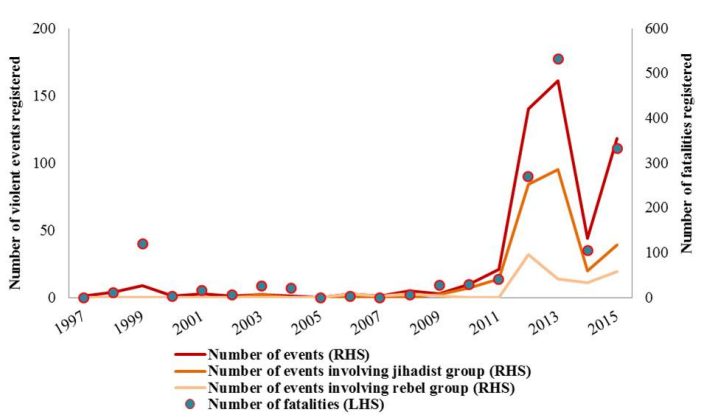

(b) Yearly 1997-2015 recorded violence (Kidal excluded)

Note: Riots, demonstrations and imprecisely localized events are excluded from the figures.

Sources: ACLED, GADM, WorldMap. Authors' computations.

Obviously, the usual drawbacks associated with event location databases hold, but we are confident that they are mitigated here. Poor information source networks in the field could imply event under-reporting (de Montclos et al., 2016). However, they do provide an unparalleled description of the occurrence and frequency of the main events. ${ }^{21}$ Furthermore, they apply at a much lower level in Mali than in other studied

\footnotetext{
${ }^{18}$ There are 49 districts, 302 sub-districts and 703 communes. Sub-district size is small enough to ensure analytical accuracy and reliability.

${ }^{19}$ GPS-SHaSA data are collected by the fourth round of EMOP from January to March or April of each year.

${ }^{20}$ We assume that violent events are more likely to escape the attention of information sources in already heavily exposed areas (where violent events become tragically mundane) than in more rarely exposed areas.

${ }^{21}$ In Mali, the number of events recorded by ACLED from 2012 to 2015 is approximately five times higher than in the
} 
contexts. First, as the Malian conflict started recently, there are more information sources on the ground and they are of higher quality. The involvement of international forces (both from France and the international community) should enhance event reporting. Last but not least, Figures B1 in the online appendix shows that ACLED is globally consistent with the Malian conflict's perceived reality, and vice versa. Citizens living in the most exposed districts are the most scared of the threat of armed conflict (districts shaded in black). Districts where individuals are the least frightened (vertical lines) are very marginally exposed areas.

\subsection{Empirical strategy}

To explore the impact of armed conflict on social capital, we estimate the following model:

$$
Y_{i, s d, t}=\alpha+\beta E v O c c_{s d,(t-1)}+\gamma X_{i, s d, t}+\delta E t h n F r_{s d, 2009}+\eta D_{d}+\theta T_{t}+\epsilon_{i, s d, t}
$$

where $Y_{i, s d, t}$, our dependent variable, denotes the social capital (or trust) of individual $i$ in sub-district $s d$ at time $t$. It is a dummy variable either denoting that individual $i$ is a member of an association (or not) or that individual $i$ is trustful (or not). $E v O c c_{s d,(t-1)}$ is our main variable of interest. It takes the value of 1 if one or more violent events were recorded in sub-district $s d$ in year $t-1$ and 0 otherwise. $X_{i, s d, t}$ is a vector of individual characteristics including gender, age group, level of education, link with the household head, marital status and area of residence (urban-rural). EthnFr ${ }_{s d, 2009}$ is a measure of ethnolinguistic fractionalisation at sub-district level. It tracks findings regarding the role of group homogeneity in participation Alesina and La Ferrara (2000). It corresponds to the conventional index of ethnolinguistic fractionalisation and is computed from the 2009 Malian census (RGPH). It measures the probability of two randomly selected people in a given area belonging to different ethnolinguistic groups. ${ }^{22}$ District dummies and year dummies, $D_{d}$ and $T_{t}$ respectively, are also included to control for local time-invariant and country time-variant unobservables. $\epsilon_{i, s d, t}$ is the error term. All estimations are robust and adjusted for clustering at year and sub-district levels. For ease of interpretation, we estimate this model using a linear probability model (LPM).

One obvious concern is the possible endogeneity of our variable of interest: violent event occurrence. In our case, endogeneity has two potential origins: reverse causality and omitted variable bias. First, people could be targeted (or engage) in the conflict on the basis of their social preferences. Targeting the places where social cohesion is strongest might be an envisaged strategy, as a way for insurgents to both symbolically and quantitatively maximise the scope (via information) of their acts and disrupt the most tightly knit regions. The opposite could also hold true. Targeting the least cohesive places could be a way to fuel resentment between groups and conduct a "divide and rule" strategy. An examination of the Malian context and data leads us to argue that reverse causality is unlikely. The pre-conflict period sample shows that there are no significant differences in participation between the locations affected and unaffected ex-post by the conflict. ${ }^{23}$ The pattern of violent events does not support a particular targeting strategy of

\footnotetext{
Uppsala Conflict Data Program due to more restrictive inclusion criteria (Croicu and Sundberg, 2015).

${ }^{22}$ The ethnolinguistic fragmentation score is calculated as equal to 1 minus the Herfindahl index, based on the mother tongue.

${ }^{23}$ Estimates are reported in online appendix Table B2. Results hold for aggregated participation and participation in family, political, professional and local associations. Engagement in religious associations appears to be lower (at $10 \%$ significance level) in future exposed areas.
} 
populations, communities or ethnic groups. ${ }^{24}$ Insurgents rather seem to follow the main routes crossing the country from north to south. By 2015, all the largest cities had suffered conflict-related violence, and all regions had experienced violent events (see Figure 2a).

Second, conflict may be determined by a third factor time-varying or not, which also influences social preferences and group membership. For instance, areas with easier access to markets or better economic performance could be more prone to conflict-related violence (Berman et al., 2017), as targeting is less costly, as well as it favours social interactions and group membership through impersonal exchange (Colletta and Cullen, 2000).

To deal with potential omitted variable biases we include district and year dummies in all estimations. We further alleviate this bias by including a large set of individual, district or sub-district-level controls in complementary estimations. Following Altonji et al. (2005) and Oster (2019) procedures, we also measure the minimum size of unobservables relative to observables required to explain away the effects of occurrence of violence on social capital.

To further mitigate potential endogeneity biases, we estimate instrumental variables (IV) and differencein-differences (DiD). Both methods are complementary. IV addresses endogeneity biases but are subject to relative imprecision, especially when both endogenous and outcome variables are binary (Chiburis et al., 2012). We instrument the occurrence of violent events by an interaction between local historical tensions and precipitation. We discuss the IV identification strategy in sub-section 4.2. DiD addresses endogeneity biases with more accuracy. DiD controls for unobserved heterogeneity between the control group, inhabitants of never affected sub-districts, and the treatment group, individuals living in sub-districts exposed to conflictrelated violence between 2006 and the year prior to the survey. It addresses the omitted variable biases, including potential spurious dynamic correlations as the specification includes time-varying region dummies. Nevertheless, different unit of observation of participation and absence of interpersonal trust measure in the 2006 sample limit its implementation.

Lastly, selection into migration is likely to bias the effects of violence if displaced individuals are systematically less or more pro-social. Constrained $\mathrm{DiD}$ estimations to non-migrants, ${ }^{25}$ enable to rule out selection into migration.

\section{Conflict and participation in associations}

\subsection{Baseline results}

Table 1 reports the baseline results. To save space, the coefficients of the control variables are not reported. All control variables are intuitively signed and consistent with the existing literature on the determinants of participation in associations (Alesina and La Ferrara, 2000). ${ }^{26}$ People living in rural areas and educated adults are more likely to be involved in associations. Ethnolinguistic fragmentation at sub-district level negatively, but non-significantly, influences membership in local associations. This result supports the findings reported by Alesina and La Ferrara (2000) regarding the role of group homogeneity in participation.

Results show a positive relationship between violent events and participation in Mali. Indeed, individuals exposed to violent events are 13 percentage points more likely to be a member of at least one association

\footnotetext{
${ }^{24}$ Event location and ethnolinguistic fragmentation is depicted in online appendix Figure B2.

${ }^{25} 2015$ is the only round of EMOP with available data on migration.

${ }^{26}$ Benchmark results are presented in online appendix Table B1.
} 
(column 1). These results are driven by participation in political associations (column 3). The likelihood of engaging in a political association increases by 10 percentage points in sub-districts exposed to violent events. In exposed areas, an individual's probability of participating in a family association is almost 5 percentage points higher. Although the coefficient is not significant, it is close to the $10 \%$ threshold. Participation in professional (column 4) and local (column 5) associations increases non significantly. The coefficient associated with exposure for participation in religious associations (column 6) is close to zero and is non-significant. This latter result is not surprising in a country where $95 \%$ of the population is Muslim (GPS-SHaSA). These results demonstrate a positive relationship of the conflict on participation in associations in Mali. However, they do not necessarily support the argument of a pro-social impact. In our typology, political and family associations are Olsonian, inward-looking organisations. Indeed, the most impacted associations, political associations, are depicted in the literature as driven by sectarianism and cronyism (Bouju, 2000; Roy, 2005). Family associations are also characterised by obvious kinship-based membership.

Table 1: Participation in associations and occurrence of violent events

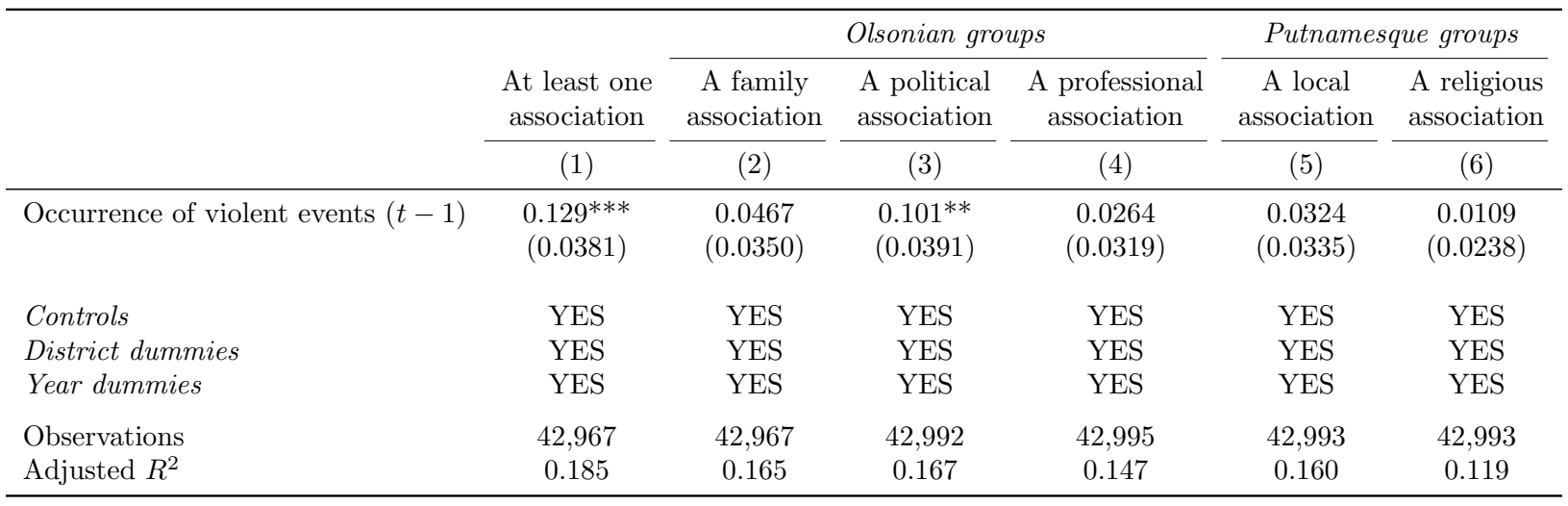

Note: Estimations are at individual level. Robust standard errors are in parentheses (adjusted for clustering at year and sub-district levels). All estimations include individual characteristics (gender, age group, level of education, relationship to household head and marital status), 2009 sub-district ethnolinguistic fragmentation and an urban-rural variable. Violent events are identified at sub-district level. Significance levels: ${ }^{* * *} \mathrm{p}<0.01,{ }^{* *} \mathrm{p}<0.05,{ }^{*} \mathrm{p}<0.1$.

Sources: GPS-SHaSA modules, EMOP, RGPH, ACLED. INSTAT-Mali, DIAL-IRD, ACLED. Authors' calculations.

We test the sensitivity of our results in various ways. We use the number of events instead of the binary variable of occurrence. Estimations reported in online appendix Table B3 confirm the greater accuracy of using a binary variable. The right-skewed distribution of the number of events and outliers makes it hard to identify a scaled impact on participation. Replacing the count of events with a categorical variable confirms that outliers tend to drive downward the effects on participation at the intensive margin. The results of specifications including the number of violent events and their square are not robust to time window variations. Besides, the results remain robust to the use of alternative time windows for the occurrence of violence. The effects of violence on participation in associations appear to be marginally lower than the baseline estimates for the occurrence of violence measured since 2012 (column 5) and in the previous two years (column 6). Occurrence of violence increases the likelihood of association participation from 8 to 10 percentage points depending on the time window. This suggests that the effect of violence on participation tends to decrease over time in rarely hit localities. The results are also robust to the exclusion of control 
variables. For further robustness checks, we use firstly participation in associations at household level as the dependent variable, and, secondly, aggregated violent events at commune level. Results remain very similar. Logit estimates remain very consistent (reported in online appendix Table B4). The results, reported in online appendix Table B5, are also consistent with the exclusion of northern Mali observations.

To test for an omitted variable bias, we add to the baseline estimations additional controls that might explain changes in participation. First, we introduce geo-climatic information starting with variables capturing climate variations. Indeed, climate shocks are among the most intuitive events that might directly affect participation and indirectly affect conflict through the channel of economic growth (Miguel et al., 2004; Hsiang et al., 2013). A standardised rainfall deviation from the past ten years of yearly-average precipitation (2005-2015 period) is calculated at district level using the Climate Research Unit dataset (version 3.24). A two-year lag is also included in the baseline estimation. We also include log-linear distance from sub-district centroids to primary roads as a proxy for market access. Second, we take advantage of the specific information contained in EMOP and particularly the GPS-SHaSA modules to include additional individual controls. We include per capita consumption quintiles, the individual level of fear due to the threat of terrorism and armed conflict, reported injury or illness in the past three months (available in the 2015 and 2016 questionnaires), stated local tensions in the previous year in the respondent's place of residence and stated access to the administration. Results are reported in appendix Table A3. The results are highly consistent and robust regardless of the specification. Additional controls do not change the consistency of our previous estimations and confirm the rising effects of exposure to conflict-related violent events on participation in associations.

Following Altonji et al. (2005), we further mitigate the omitted variable bias by measuring the relative size of unobservables to observables necessary to explain away the effect of violence on participation. It consists in comparing coefficients of violence occurrence between baseline estimations with controls and baseline estimations without control (but with district dummies). The estimation with controls is limited to baseline specification. ${ }^{27}$ Unobservables should be 3 times larger than observables to explain away the effects of violence on participation in at least one association and in political associations. This result is confirmed by Oster (2019) improved procedure which takes into account the change of R-squared from estimations without control to estimations with controls. ${ }^{28}$ Unobservables need to be 3 times larger than observables to explain away the effect of violence on participation in at least one association. ${ }^{29}$ This ratio is estimated for a maximum R-squared corresponding to 1.3 times the baseline R-squared (as suggested in Oster, 2019). These results suggest that omitted variable bias is unlikely. Nevertheless, this result does not completely rule out endogeneity biases. The following sub-sections use two complementary estimation strategies (IV and DiD) to further address potential endogeneity biases. It also considers potential selection into migration.

\footnotetext{
${ }^{27}$ The ratio equals $\frac{\tilde{\beta}_{\text {control }}}{\hat{\beta}_{\text {nocontrol }}-\tilde{\beta}_{\text {control }}}$ where $\tilde{\beta}_{\text {control }}$ is the coefficient of violence occurrence in baseline estimation with controls and $\hat{\beta}_{\text {nocontrol }}$ is the same coefficient in the uncontrolled specification.

${ }^{28}$ We use Oster (2019) Stata command psacalc to estimate the ratio.

${ }^{29}$ The size of unobservables needs to be the same as observables to explain away the effect of violence on participation in political associations.
} 


\subsection{Identifying a causal relationship}

\section{Instrumental variable estimations}

Although we argue in sub-section 3.2 that there is no statistical evidence suggesting a problem of reverse causality, potential endogeneity issues cannot be ruled out definitively. To overcome such biases, we first conduct an instrumental variable estimation on participation in associations. We instrument the occurrence of violent events by an interaction between local historical tensions and precipitation. The reason behind the choice of this instrument is that climate variations are conducive to violence, especially in areas with structural tensions, revealed by past violence. In Mali, some areas are exposed to local tensions, mainly land disputes and ethnic opposition, which cause scattered violence (Leclerc-Olive, 2017). The use of an interacted instrument is inspired by Nunn and Qian (2014). To estimate the effect of United States (US) food aid on the incidence of conflict in recipient countries, they instrument US food aid by an interaction of lagged US wheat production with a country's propensity to receive US food aid. Similarly, our interacted instrument exploits both cross-sectional variation in historical tensions and time and cross-sectional variations in precipitation. The interacted instrument also strengthens the fit of our first stage.

To identify local historical tensions, we use ACLED data and compute a dummy variable denoting the occurrence of a violent event in the sub-district in a peaceful time (i.e. over the 1997-2005 period). ${ }^{30}$ The precipitation variable is a standardised measure of the deviation of the previous year's rainfall from the past ten years (2005-2015) of annual average precipitation at district level. There is considerable evidence of the role of rainfall and weather variations in the onset of conflict (see, for instance, Couttenier and Soubeyran, 2015, for an overview; see also Miguel et al., 2004; Koubi et al., 2012; Harari and La Ferrara, 2018). The transmission channels of weather variations on violence can be twofold. First, through an opportunity cost mechanism, positive variations could deter from engaging in violent activities while living conditions improve, as suggested in Couttenier and Soubeyran (2014) and Harari and La Ferrara (2018). Second, on the contrary, through a rent-seeking behaviour, positive variations could also increase violence: the potential gains from winning violent confrontation increase, as it has been shown in the case of coca production in Columbia (Angrist and Kugler, 2008). This evidence does not relate exclusively to large rainfall deviations. It also concerns more marginal deviations, as reviewed in Hsiang et al. (2013).

There may be some concern that weather shocks and historical tensions might determine contemporary participation in groups. Should this be the case, the exclusion criterion would be violated. We argue that this is unlikely. Substantial weather shocks, including drought and floods, may have a direct effect on participation in associations, especially those playing an informal insurance role. However, such shocks are not observed over the 2012-2015 period, which presents between -2 and +2 standard deviations. For historical tensions, although occurrences of violence are found across all regions of Mali, they are rare and highly localised in time and space. These violent events are associated with neither jihadist nor Tuareg violence nor any potential ideological combat. They are due rather to criminal activity and local disputes. Moreover, not only is past violence rare, but it is not recurrent. Only two sub-districts were affected by violence more than once (twice in Bamako and three times in Gao) over eight years. It is therefore unlikely that past violence drove the creation of or participation in groups, including self-defence groups. The falsification tests reported in Table 2 confirm that neither past violent events (column 1 without district

\footnotetext{
${ }^{30} 1997-2005$ events are mapped in appendix Figure A2.
} 
dummies, column 2 with district dummies) nor its interaction with 2005 standardised measure of rainfall deviation from 1995-2005 annual average precipitation at district level (column 2) do not significantly impact on participation in 2006. Lastly, we include district dummies to partly mitigate the risk that unobserved third factors may affect both past violence and current participation. For instance, villages exposed to violence in the past might be thought to have created paramilitary groups, which the conflict is reforming today. This scenario is unlikely in the case of Mali. As explained previously, violence was rare and not recurrent from 1997 to 2005. Before the 2012 crisis, and especially prior to 2006, Mali was widely considered as a peaceful country and even presented as a regional model for its stability. The country presents no evidence of armed sleeper groups.

Table 2: Falsification tests and IV first-stage estimates

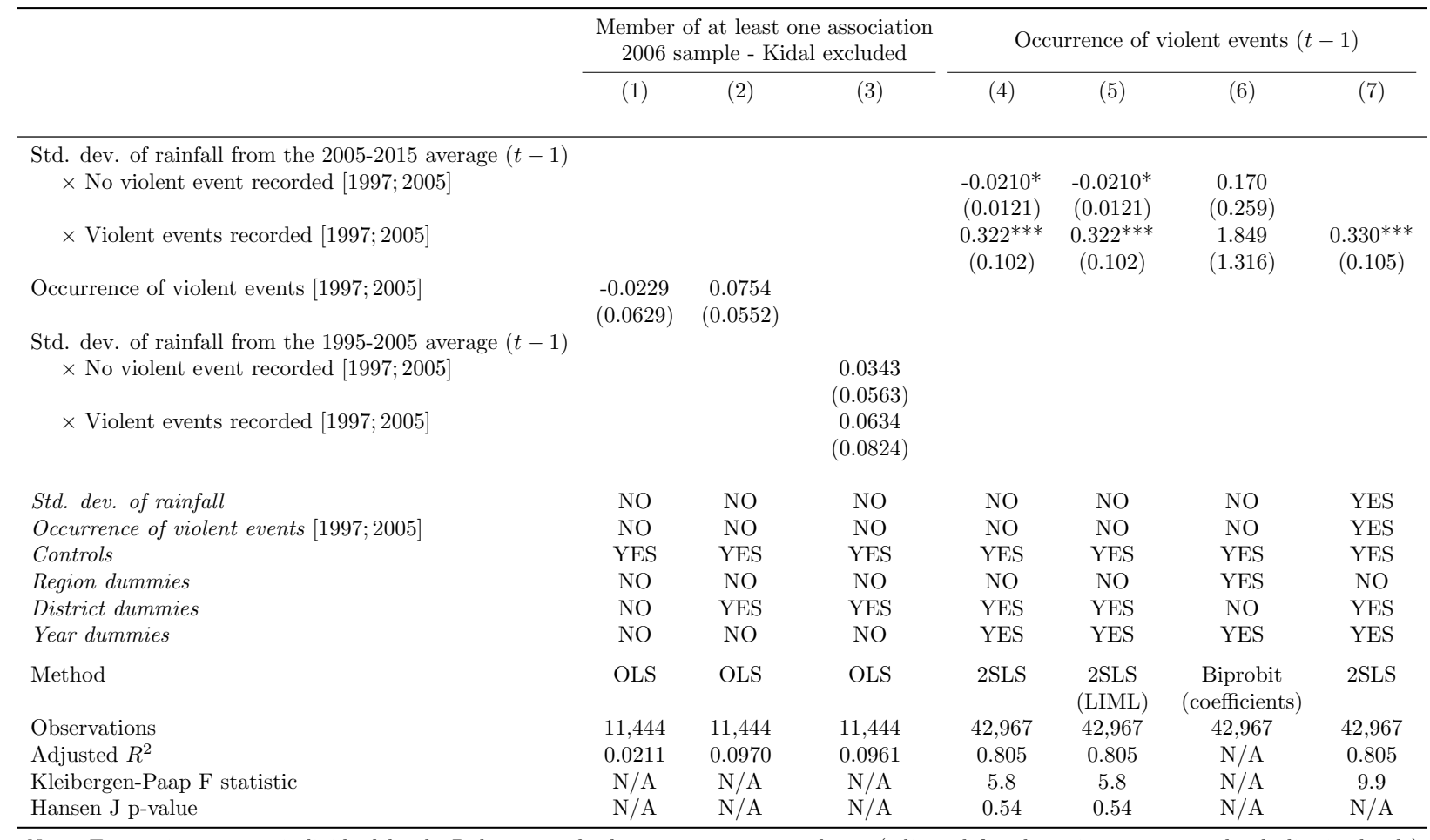

Note: Estimations are at individual level. Robust standard errors are in parentheses (adjusted for clustering at year and sub-district levels). All estimations include individual characteristics (gender, age group, level of education, relationship to household head and marital status), 2009 sub-district ethnolinguistic fragmentation and an urban-rural variable. Violent events are identified at sub-district level. Significance levels: $* * * \mathrm{p}<0.01, * * \mathrm{p}<0.05, * \mathrm{p}<0.1$.

Sources: GPS-SHaSA modules, EMOP, ELIM, RGPH, ACLED. INSTAT-Mali, DIAL-IRD, ACLED. Authors' calculations.

The first-stage IV estimates are reported in Table 2. The relatively low F-statistic suggesting a weak instrument bias. Nevertheless, the implementation of just-identified IV estimation by additionally including the variables of rainfall deviation and occurrence of violent events during the 1997-2005 period in the firstand second-stage estimations also confirms the relative strength of the estimation. Indeed, as estimates remain highly consistent, the Kleibergen-Paap F-statistic reaches the traditional threshold of 10 (column 7). Furthermore, a comparison of the Kleibergen-Paap F-statistic with the usual thresholds (Stock and Yogo, 2005) does not apply here, as estimations are adjusted for clustering (Rohner et al., 2013). Positive rainfall deviations are likely to increase exposure to conflict-related violent events in areas historically tensed, and 
rather decrease otherwise. The latter effect is small and significant at $10 \%$. These results can be interpreted in the light of the economic literature on the causes of civil war. The opportunity cost channel may prevail in areas unaffected by past violence in Mali. It might then explain the negative impact of positive rainfall variations on the occurrence of violence. A rent-seeking behaviour should be at stake in Malian land disputed localities. Indeed, potentially higher rewards due to positive rainfall deviations may explain the greater likelihood of the occurrence of violence.

Table 3: Participation in associations and occurrence of violent events (Reduced form and IV second-stage)

\begin{tabular}{|c|c|c|c|c|c|}
\hline & & Membe & of at least one & ssociation & \\
\hline & $(1)$ & $(2)$ & $(3)$ & $(4)$ & $(5)$ \\
\hline Occurrence of violent events $(t-1)$ & & $\begin{array}{l}0.356^{* *} \\
(0.168)\end{array}$ & $\begin{array}{c}0.356^{* *} \\
(0.168)\end{array}$ & $\begin{array}{l}0.228^{* * *} \\
(0.0690)\end{array}$ & $\begin{array}{l}0.340^{*} \\
(0.178)\end{array}$ \\
\hline $\begin{array}{l}\text { Std. dev. of rainfall from the } 2005-2015 \text { average }(t-1) \\
\times \text { No violent event recorded }[1997 ; 2005] \\
\times \text { Violent events recorded }[1997 ; 2005]\end{array}$ & $\begin{array}{l}-0.0150 \\
(0.0131) \\
0.107^{* *} \\
(0.0430)\end{array}$ & & & & \\
\hline Anderson-Rubin 95\% confidence interval & $\mathrm{N} / \mathrm{A}$ & {$[0.0113,0.701]$} & {$[0.0110,0.701]$} & $\mathrm{N} / \mathrm{A}$ & {$[0.0312,0.649]$} \\
\hline $\begin{array}{l}\text { Std. dev. of rainfall } \\
\text { Occurrence of violent events }[1997 ; 2005] \\
\text { Controls } \\
\text { District dummies } \\
\text { Year dummies }\end{array}$ & $\begin{array}{l}\text { NO } \\
\text { NO } \\
\text { YES } \\
\text { YES } \\
\text { YES }\end{array}$ & $\begin{array}{l}\text { NO } \\
\text { NO } \\
\text { YES } \\
\text { YES } \\
\text { YES }\end{array}$ & $\begin{array}{l}\text { NO } \\
\text { NO } \\
\text { YES } \\
\text { YES } \\
\text { YES }\end{array}$ & $\begin{array}{l}\text { NO } \\
\text { NO } \\
\text { YES } \\
\text { YES } \\
\text { YES }\end{array}$ & $\begin{array}{l}\text { YES } \\
\text { YES } \\
\text { YES } \\
\text { YES } \\
\text { YES }\end{array}$ \\
\hline Method & OLS & 2SLS & $\begin{array}{c}2 \mathrm{SLS} \\
(\mathrm{LIML})\end{array}$ & $\begin{array}{l}\text { Biprobit } \\
\text { (marg. eff.) }\end{array}$ & 2SLS \\
\hline $\begin{array}{l}\text { Observations } \\
\text { Adjusted } R^{2}\end{array}$ & $\begin{array}{c}42,967 \\
0.183\end{array}$ & $\begin{array}{c}42,967 \\
0.178\end{array}$ & $\begin{array}{c}42,967 \\
0.178\end{array}$ & $\begin{array}{c}42,967 \\
\mathrm{~N} / \mathrm{A}\end{array}$ & $\begin{array}{c}42,967 \\
0.179\end{array}$ \\
\hline
\end{tabular}

Note: Estimations are at individual level. Robust standard errors are in parentheses (adjusted for clustering at year and sub-district levels). All estimations include individual characteristics (gender, age group, level of education, relationship to household head and marital status), 2009 sub-district ethnolinguistic fragmentation and an urban-rural variable. Violent events are identified at sub-district level. Significance levels: ${ }^{* * *} \mathrm{p}<0.01,{ }^{*} \mathrm{p}<0.05,{ }^{*} \mathrm{p}<0.1$.

Sources: GPS-SHaSA modules, EMOP, RGPH, ACLED. INSTAT-Mali, DIAL-IRD, ACLED. Authors' calculations.

The reduced form and second-stage IV estimates are reported in Table 3. The reduced form (column 1) confirms the expected effect of the instrument on participation. Increased rainfall positively affects participation in areas previously exposed to violent events. The second-stage IV estimation consistently shows a positive effect of conflict on participation in associations. As expected, the precision of the impact of the occurrence-of-violence coefficient on association participation is weaker than in the baseline estimation. This difference of magnitude is due to the relatively lower precision of two-stage least squares (2SLS) when both outcome variable and endogenous variable are binary, as described in Chiburis et al. (2012). We use the limited information maximum likelihood (LIML) estimator (column 3) to further mitigate the estimation biases due to potentially weak instruments (Angrist and Pischke, 2009). The results remain highly consistent with the previous estimates. In addition, corrected confidence intervals for weak-instrument robust inference based on Anderson and Rubin (1949) test confirm the direction and the significance of the effect of occurrence of violent events. Bivariate probit estimates, relatively more precise alternative to the 2SLS estimation method (Chiburis et al., 2012), remain very robust (column 4). As the latter estimation method is based on more restrictive hypotheses, district dummies need to be substituted by region dummies in 
the first-stage estimation. ${ }^{31}$ As reported in appendix Table A4, IV estimates confirm that participation is mainly, if not exclusively, driven by participation in inward-looking groups.

\section{Difference-in-differences estimations}

We round out the IV estimation methods with a DiD estimation method applied to repeated cross-section data (Wooldridge, 2009). IV estimates provide unbiased estimates under certain restrictions. Aside from the difficulty of finding a satisfactory instrumental variable, IV estimates in our case are less precise due to the fact that our outcome and endogenous variables are both binary (Chiburis et al., 2012). DiD estimates are usually more accurate and able to rule out potential reverse causality bias and mitigates the risk of unobserved heterogeneity between the control group and treatment group for all association types. The pooled ELIM 2006 sample is identified as the pre-treatment period, while the GPS-SHaSA samples are used as the post-treatment period. As mentioned above, participation data is measured at household level in 2006. To ensure that harmonised, consistent scales are used for the analysis, we assume that all adult household members in the post-2012 samples were asked about their involvement in associations. ${ }^{32}$ Hereafter, we use a binary dependent variable taking the value of 1 if an adult belongs to a household in which at least one member is part of an association and 0 otherwise. ${ }^{33}$ The treatment is the occurrence of violent events at sub-district level from 2006 to $2015 .{ }^{34}$ Treated adults are those who live in a sub-district affected by one or more violent events since 2006, while the control group includes adults living in sub-districts that were never affected by violent events in the same time period. Formally, the DiD estimation method can be modelled as follows:

$$
\begin{aligned}
& Y_{i, s d, t}=\alpha+\beta E v O c c_{s d,[2006 ;(t-1)]}+\lambda \text { Post } 2012_{t}+\mu\left(E v O c c_{s d,[2006 ;(t-1)]} \times{\text { Post } \left.2012_{t}\right)}\right. \\
& +\gamma X_{i, s d, t}+\delta E t h n F r_{s d, 2009}+\eta D_{d}+\theta T_{t}+\pi R_{r, 2006}+\rho R_{r, P o s t 2012}+\epsilon_{i, s d, t}
\end{aligned}
$$

where $E v O c c_{s d,[2006 ;(t-1)]}$ is a binary variable taking the value of 1 if one or more violent events were recorded in sub-district $s d$ from 2006 to the year before the survey and 0 otherwise. This variable corresponds to the difference in participation between the control and treatment groups during the pre-treatment period (2006). Post $2012_{t}$ differentiates between pre-treatment and post-treatment observations. The variable of interest is the interaction between these latter two variables, as it captures the actual impact of exposure to conflict-related violence on participation in groups. In addition to the same controls as those used in the baseline estimations, we include pre- and post-treatment regional dummies to capture for regional structural changes between the two periods. This interaction addresses the potential dynamic omitted variable bias by capturing the most radical changes in infrastructures across regions over time. Robust standard errors are adjusted for clustering at sub-district level.

The DiD estimation rests upon a strict common trend assumption. Under this assumption, the likelihood of living in a household with an association member in exposed (treatment group) or non-exposed (control group) sub-districts would follow a parallel trend if the conflict were not observed, which is a very strong

\footnotetext{
${ }^{31}$ The results remain consistent with the district dummies, but the first-stage equation is likely to be misspecified.

${ }^{32}$ This could be problematic for households comprising four or more adults. However, this is a minor approximation, as it affects less than $5 \%$ of the adults in our post-conflict pooled sample. Sensitivity checks and the correlation between household and individual measures (from 0.7 to 0.8 ) confirm the absence of bias due to such measurement errors.

${ }^{33}$ Group membership of one household member impacts the rest of the household members (Jackson et al., 2012).

${ }^{34}$ Since $92 \%$ of the violent events recorded from 2006 to 2015 took place and were the most intense in 2012 and after, the effects of being exposed to violent events are attributed to the 2012 conflict.
} 
assumption that cannot be tested. Nonetheless, as presented in Figure 2a, the very great extent to which the conflict affects the Malian territory reduces the concerns of local heterogeneity in participation between control and treatment groups and supports the parallel trend assumption. To further check the relevance of this assumption, the best available option is to reconsider the treatment period from 2014 onwards, as if violent events had only been observed since 2014. We thus use a sub-sample to compare participation for the 2006-2014 period in sub-districts not affected since 2006 with sub-districts affected solely from 2014 onwards. Figure 3 reports the estimated fitted values of the likelihood of an individual living in a household with at least one association member (regardless of type) between unaffected and affected sub-districts in 2014 and after. The results argue strongly in favour of the existence of a parallel trend. ${ }^{35}$ Placebo tests with randomly assigned treatment status and randomly assigned outcome variables further support the parallel trend assumption. ${ }^{36}$

Figure 3: Participation trends

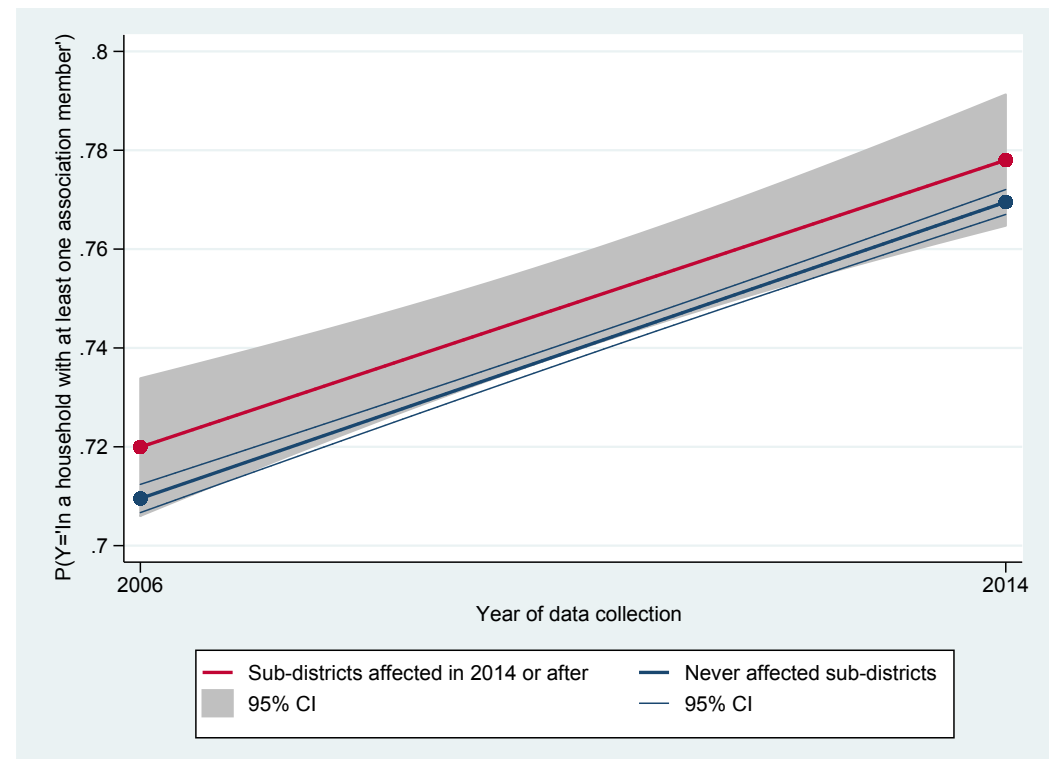

Sources: GPS-SHaSA modules, EMOP 2014, ELIM 2006, ACLED. INSTAT-Mali, DIAL-IRD, ACLED. Authors' computations.

The results of the DiD estimations are presented in Table 4. Overall, participation increased by 8 percentage points from 2006 to the conflict period regardless of treatment status (coefficients of the post-2012 dummy variable). The general trend in participation from 2006 to the post-conflict period highlights a shift in participation from family and religious associations (columns 2 and 6) to local and professional associations (columns 3 and 5). Participation does not differ significantly in 2006 between the control and treatment groups (coefficients of the occurrence variable), further mitigating reverse causation. The sub-districts exposed to violence since 2006 do not present higher participation. As for the effects of conflict-related violent events (coefficient of interaction), the results remain very robust to the previous estimation methods.

\footnotetext{
${ }^{35}$ See the estimates reported in appendix Table A5. The trend estimates support the assumption of a common trend for all types of association. The inclusion of individuals exposed to violence since 1997 does not change the estimation results.

${ }^{36}$ A summary of the results are reported in online appendix Table B6.
} 
Being exposed to conflict-related violence increases the likelihood of participation in associations even if the coefficients are not significant (column 1). This upward trend in participation in exposed areas is driven by the significant positive impact on membership in family and political associations, which is consistent with our previous estimates. Indeed, being exposed to conflict increases participation by respectively 14 and 11 percentage points. Participation in local, professional and religious associations is not significantly affected by the occurrence of violent events in Mali.

DiD estimates confirm our main findings: conflict-related violent events increase participation in associations, but these results are driven by increased participation in inward-looking associations (family and political groups).

Table 4: Participation in associations and occurrence of violent events (DiD)

\begin{tabular}{|c|c|c|c|c|c|c|}
\hline & \multirow[b]{2}{*}{$\begin{array}{c}\text { At least one } \\
\text { association }\end{array}$} & \multicolumn{3}{|c|}{ Olsonian groups } & \multicolumn{2}{|c|}{ Putnamesque groups } \\
\hline & & $\begin{array}{c}\text { A family } \\
\text { association }\end{array}$ & $\begin{array}{l}\text { A political } \\
\text { association }\end{array}$ & $\begin{array}{l}\text { A professional } \\
\text { association }\end{array}$ & $\begin{array}{c}\text { A local } \\
\text { association }\end{array}$ & $\begin{array}{l}\text { A religious } \\
\text { association }\end{array}$ \\
\hline & $(1)$ & $(2)$ & $(3)$ & $(4)$ & $(5)$ & (6) \\
\hline Post-2012 dummy & $\begin{array}{l}0.0795^{*} \\
(0.0437)\end{array}$ & $\begin{array}{c}-0.106^{* * *} \\
(0.0398)\end{array}$ & $\begin{array}{c}-0.00885 \\
(0.0358)\end{array}$ & $\begin{array}{c}0.105^{* * *} \\
(0.0339)\end{array}$ & $\begin{array}{c}0.203^{* * *} \\
(0.0605)\end{array}$ & $\begin{array}{c}-0.169^{* * *} \\
(0.0385)\end{array}$ \\
\hline Occurrence of violent events $[2006 ;(t-1)]$ & $\begin{array}{r}-0.00848 \\
(0.0503)\end{array}$ & $\begin{array}{l}-0.0875 \\
(0.0596)\end{array}$ & $\begin{array}{l}-0.0203 \\
(0.0396)\end{array}$ & $\begin{array}{c}0.0292 \\
(0.0401)\end{array}$ & $\begin{array}{l}-0.0242 \\
(0.0451)\end{array}$ & $\begin{array}{l}-0.0218 \\
(0.0296)\end{array}$ \\
\hline Post-2012 × Occurrence & $\begin{array}{c}0.0770 \\
(0.0583)\end{array}$ & $\begin{array}{c}0.140^{*} \\
(0.0742)\end{array}$ & $\begin{array}{c}0.116^{* * *} \\
(0.0424)\end{array}$ & $\begin{array}{c}0.0352 \\
(0.0410)\end{array}$ & $\begin{array}{c}0.0535 \\
(0.0555)\end{array}$ & $\begin{array}{c}0.0309 \\
(0.0337)\end{array}$ \\
\hline Controls & YES & YES & YES & YES & YES & YES \\
\hline District dummies & YES & YES & YES & YES & YES & YES \\
\hline Year dummies & YES & YES & YES & YES & YES & YES \\
\hline Region $\times$ Post-2012 dummies & YES & YES & YES & YES & YES & YES \\
\hline Observations & 54,878 & 54,860 & 54,883 & 54,888 & 54,891 & 54,892 \\
\hline Adjusted $R^{2}$ & 0.129 & 0.120 & 0.138 & 0.140 & 0.169 & 0.0852 \\
\hline
\end{tabular}

Note: Estimations are at individual level. Robust standard errors are in parentheses (adjusted for clustering at sub-district level). All estimations include individual characteristics (gender, age group, level of education, relationship to household head and marital status), 2009 sub-district ethnolinguistic fragmentation and an urban-rural variable. Violent events are identified at sub-district level. Significance levels: ${ }^{* * *} \mathrm{p}<0.01,{ }^{*} \mathrm{p}<0.05,{ }^{*} \mathrm{p}<0.1$.

Sources: GPS-SHaSA modules, EMOP, ELIM, RGPH, ACLED. INSTAT-Mali, DIAL-IRD, ACLED. Authors' calculations.

\section{Selection into migration}

Selection into migration is a source of concern in studies on the micro-effects of conflicts. In Mali, the crisis forced almost 400,000 people to flee from their hometowns, particularly from the Timbuktu and Gao regions, to neighbouring regions or countries in 2012 and 2013 (IOM, 2014a). The majority of those who fled violence and lived in refugee camps abroad (Burkina Faso, Mauritania and Niger) did not come back and so cannot be taken into account by the available data, which is a source of limitation for the present findings. Nonetheless, the majority of the displaced population (61\%) moved to neighbouring Malian areas, mainly to Bamako and the Mopti and Segou regions. Internally displaced persons (IDPs) also moved within the north (representing more than $30 \%$ of IDPs). A substantial share of IDPs spontaneously returned to their place of origin before the 2013 presidential elections (UNHCR, 2014). By the end of 2014, approximately $80 \%$ of IDPs had returned to their hometowns (IOM, 2014b). Still, more than 50,000 IDPs were recorded in 2016 (UNHCR, 2016). Those displaced individuals could bias our results if their social characteristics 
were found to differ from the rest of the population. If displaced adults are less pro-social, as documented by Gilligan et al. (2014) in the case of the Nepalese civil war, our results would be overestimated. Less pro-social individuals would then lower the actual levels of participation in groups in non-exposed areas. Conversely, IDPs could conceivably be more pro-social, resulting in the underestimation of impacts, or as social as others.

We have data on migration for 2015. They show that migrants are younger and more educated. These two characteristics have opposite effects on the probability of participating in an association. It is thus unclear how migrants would bias our results. To control for selection into migration, we exclude from the 2015 sample all adults who migrated in the past ten years (almost 2,000 observations) and recalibrate the participation measure. The characteristics of the adults interviewed in 2006 should not differ from those interviewed in 2015. The results of the unconstrained (panel A) and constrained (migrants excluded, panel B) DiD estimations are presented in appendix Table A6. The results are consistent with the baseline estimation and rule out selection into migration.

\section{Going further: Are strong ties favoured?}

\subsection{Participation in fragmented areas}

If being exposed to violent events robustly implies an increase in participation in associations, this concerns primarily family and political associations. Family associations concern only kinship-based related adults, while political associations are described in the literature as a necessary tool for satisfying particular groups' interests in Mali (Roy, 2005). The latter's cronyism practices in favouring in-groups are documented, as in Roy (2010). Other types of associational membership seem to be affected more heterogeneously by the conflict. Participation in more heterogeneously-composed associations is impacted at much lower levels and non-significantly, compared with participation in family or political associations. This is particularly the case with local development associations, which account for the highest number of members in Mali. Local associations are central to local development, replacing weak or absent institutions to provide public goods such as health and education infrastructures. Their intrinsic role implies a certain representativeness of the different groups' interests. These results hence suggest that kinship-based interactions are favoured in the case of exposure to violent events, perhaps at the expense of bridging ties via an exclusion process. Therefore, our results tend to indicate that only bonding social capital, via inward-looking organisations, has increased.

The available data do not enable us to directly identify adults' withdrawal within their own groups in conflict-affected areas. For instance, we are not able to observe the associations' compositions. However, we are able to further investigate this hypothesis by studying associational membership in highly heterogeneous localities versus more homogeneous localities. In Mali, some associations, particularly local associations, have to take into account the concerns of all groups living in the same area to serve the general interest. As they need to achieve some local representativeness, local associations ought to be somewhat heterogeneously composed in fragmented areas. If bridging ties are actually deteriorating in Mali, participation in local associations would be negatively affected by violence in the most fragmented areas. Simultaneously, participation would increase in associations based on kinship ties. To differentiate homogeneous and heterogeneous 
areas, we use an ethnolinguistic fractionalisation index at sub-district level as mentioned in sub-section 3.1. ${ }^{37}$ DiD is implemented separately for the homogeneous and heterogeneous sub-samples using a threshold of 0.4 (ethnolinguistic fragmentation mean and median in Mali).

Table 5: Participation and occurrence of violent events in fragmented areas

\begin{tabular}{|c|c|c|c|c|c|c|}
\hline & \multirow[b]{2}{*}{$\begin{array}{l}\text { At least one } \\
\text { association }\end{array}$} & \multicolumn{3}{|c|}{ Olsonian groups } & \multicolumn{2}{|c|}{ Putnamesque groups } \\
\hline & & $\begin{array}{c}\text { A family } \\
\text { association }\end{array}$ & $\begin{array}{l}\text { A political } \\
\text { association }\end{array}$ & $\begin{array}{c}\text { A professional } \\
\text { association }\end{array}$ & $\begin{array}{c}\text { A local } \\
\text { association }\end{array}$ & $\begin{array}{l}\text { A religious } \\
\text { association }\end{array}$ \\
\hline & (1) & $(2)$ & $(3)$ & $(4)$ & $(5)$ & (6) \\
\hline \multicolumn{7}{|c|}{ Panel A: Homogeneous sub-districts (EthnFrag $\leq 0.4)$} \\
\hline Post-2012 × Occurrence & $\begin{array}{c}0.0354 \\
(0.0649)\end{array}$ & $\begin{array}{c}0.0139 \\
(0.0835)\end{array}$ & $\begin{array}{c}0.0954^{*} \\
(0.0532)\end{array}$ & $\begin{array}{c}0.0663 \\
(0.0675)\end{array}$ & $\begin{array}{l}0.173^{* *} \\
(0.0737)\end{array}$ & $\begin{array}{c}0.0595 \\
(0.0478)\end{array}$ \\
\hline Observations & 22,442 & 22,439 & 22,440 & 22,440 & 22,440 & 22,440 \\
\hline Adjusted $R^{2}$ & 0.140 & 0.122 & 0.129 & 0.130 & 0.146 & 0.103 \\
\hline \multicolumn{7}{|c|}{ Panel B: Fragmented sub-districts (EthnFrag >0.4) } \\
\hline Post-2012 × Occurrence & $\begin{array}{l}0.00739 \\
(0.0561)\end{array}$ & $\begin{array}{c}0.0962 \\
(0.0590)\end{array}$ & $\begin{array}{c}0.120^{*} \\
(0.0605)\end{array}$ & $\begin{array}{l}-0.0201 \\
(0.0487)\end{array}$ & $\begin{array}{l}-0.0771 \\
(0.0585)\end{array}$ & $\begin{array}{c}0.0300 \\
(0.0488)\end{array}$ \\
\hline Observations & 32,436 & 32,421 & 32,443 & 32,448 & 32,451 & 32,452 \\
\hline Adjusted $R^{2}$ & 0.143 & 0.152 & 0.155 & 0.172 & 0.195 & 0.0851 \\
\hline
\end{tabular}

Note: Estimations are at individual level. Robust standard errors are in parentheses (adjusted for clustering at sub-district level). All estimations include individual characteristics (gender, age group, level of education, relationship to household head and marital status), 2009 sub-district ethnolinguistic fragmentation, an urbanrural variable, district dummies, year dummies and pre- and post-treatment regional dummies. Post-2012 dummy and occurrence of violent events variables are also included. Violent events are identified at sub-district level. Significance levels: ${ }^{* * *} \mathrm{p}<0.01,{ }^{* *} \mathrm{p}<0.05,{ }^{*} \mathrm{p}<0.1$.

Sources: GPS-SHaSA modules, EMOP, ELIM, RGPH, ACLED. INSTAT-Mali, DIAL-IRD, ACLED. Authors' calculations.

The results are presented in Table 5. Although both sub-samples confirm the increase in participation in political associations due to exposure to violent events (column 3), they also highlight a heterogeneous impact on participation in family and local associations (columns 2 and 5). In relatively homogeneous areas (panel A), participation choices are not influenced by the types of interactions they imply, as associations are homogeneously-composed. Violence impacts mostly participation in local and political associations, whereas the effect for family associations is very close to zero and not significant. When exposed to violent events, the likelihood of participation in a local association increases by 17 percentage points in homogeneous areas. Estimates for participation in professional and religious associations (columns 4 and 6) are positive, but not significant. In more fragmented areas (panel B), the results corroborate the "strengthening of bonding ties" interpretation. Indeed, participation in inward-looking and outward looking associations is impacted oppositely by the occurrence of violent events. Even though the results are insufficiently significant (but close to the $10 \%$ threshold), violent events positively affect participation in family associations and negatively affect participation in local associations. In accordance with the conceptual framework, impacts

\footnotetext{
${ }^{37}$ We assume that migration after 2012 did not affect overall fragmentation per area, at least up to the end of our study period. The Malian conflict does not at all present an ethnic cleansing dimension, at least in the period of interest, and should not have impacted on ethnic composition.
} 
are differentiated by type of association (inward-looking or outward-looking associations). Associations based on weak ties appear to suffer from the occurrence of violent events, while the opposite holds true for those based on kinship or shared affinities, particularly family and political associations. In exposed areas, participation to the latter associations increase by 12 percentage points. The results of the subsample estimations thus confirm the strengthening of bonding ties through the empowerment of same-group interest associations. Associations that include individuals from out-groups appear to attract progressively fewer individuals. The impact of conflict on social engagement appears to foster withdrawal into one's own group rather than increased solidarity between Malians. The study of the impact of conflict-related violence on interpersonal trust is discussed in the next section and supports this interpretation.

\subsection{Effects of conflict on interpersonal trust}

Further interpretation of the impacts of conflict on participation calls for the mechanisms at stake to be understood. Given the assumed link between participation in groups and interpersonal trust (Sønderskov, 2011; Paxton and Ressler, 2017), we look into the effects of violent events on interpersonal trust. Consistently, based on the available data, individual participation in associations is positively correlated with trust in outgroups. Thus, if trust increased in affected areas, the parallel increase in participation could represent an actual improvement in social capital, which would facilitate post-war convergence with unaffected areas. Conversely, a decline in out-group trust might indicate the development of self-centred exclusive groups. The increased participation due to exposure to violent events in Mali could be then identified as a form of withdrawal rather than pro-social behaviour. Information on interpersonal trust is only available in the post-2012 samples. We keep as the dependent variable the probability of an adult trusting in a specified group. This variable takes the value of 1 when an adult trusts ("Somewhat" or "Completely") and 0 when the adult does not ("Not at all" or "Not really").

Table 6 presents the LPM baseline estimations. ${ }^{38}$ The occurrence of violence tends to significantly lower generalised trust by 11 percentage points (column 1). The results are particularly significant for trust in those with a different political opinion or a different nationality. Being affected by conflict increases distrust in the latter out-groups by 6 to 7 percentage points. Although the results for trust in other groups are not significant, they still make for interesting trends. While the coefficients for trust in out-groups, namely other ethnic groups and other linguistic groups, are negative (columns 4 and 5), the coefficient related to neighbours is positive and close to zero. Trust in relatives (column 2) is marginally, but negatively related to violence. This latter negative result could cast doubt on the hypothesis of the strengthening of kinship-based ties. However, considering the Malian reality, this result has to be qualified. First, trust in relatives is a measure which refers globally to members of the extended family. Some of them can be excluded from family associations, which gather a narrow circle of persons (the close relatives) to whom individuals fall back in their withdrawal strategy. Second, the level of trust in relatives is very high in Mali, as $95 \%$ of Malians trust their family members: a marginal decrease leaves trust in family members quite high.

We take advantage of the ordered response options offered by the interpersonal trust questions to delve deeper into the potential effects of the occurrence of violence on trust levels. Instead of using a simple positive/negative dependent binary variable, we use each response option against the other options as the dependent binary variable. For each type of trust question, we use four different dependent variables, which

\footnotetext{
${ }^{38}$ Alternative specifications were estimated. The results, reported in online appendix Table B7, remain very consistent.
} 
Table 6: Interpersonal trust and occurrence of violent events

\begin{tabular}{|c|c|c|c|c|c|c|c|}
\hline & \multirow[b]{2}{*}{$\begin{array}{c}\text { Generalised } \\
\text { trust }\end{array}$} & \multicolumn{6}{|c|}{ Trust in: } \\
\hline & & Relatives & Neighbours & $\begin{array}{c}\text { Other } \\
\text { ethnic group }\end{array}$ & $\begin{array}{c}\text { Other } \\
\text { linguistic group }\end{array}$ & $\begin{array}{c}\text { Different } \\
\text { pol. opinion }\end{array}$ & $\begin{array}{c}\text { Other } \\
\text { nationality }\end{array}$ \\
\hline & $(1)$ & $(2)$ & $(3)$ & $(4)$ & $(5)$ & (6) & $(7)$ \\
\hline Occurrence of violent events $(t-1)$ & $\begin{array}{c}-0.111^{* * *} \\
(0.0360)\end{array}$ & $\begin{array}{r}-0.0227^{* *} \\
(0.00982)\end{array}$ & $\begin{array}{c}0.0190 \\
(0.0235)\end{array}$ & $\begin{array}{l}-0.0396 \\
(0.0305)\end{array}$ & $\begin{array}{l}-0.0333 \\
(0.0306)\end{array}$ & $\begin{array}{c}-0.0720^{* *} \\
(0.0326)\end{array}$ & $\begin{array}{l}-0.0625^{*} \\
(0.0339)\end{array}$ \\
\hline Controls & YES & YES & YES & YES & YES & YES & YES \\
\hline District dummies & YES & YES & YES & YES & YES & YES & YES \\
\hline Year dummies & YES & YES & YES & YES & YES & YES & YES \\
\hline Observations & 42,936 & 42,814 & 42,987 & 42,996 & 42,995 & 42,995 & 42,966 \\
\hline Adjusted $R^{2}$ & 0.105 & 0.0744 & 0.0741 & 0.116 & 0.117 & 0.120 & 0.132 \\
\hline
\end{tabular}

Note: Estimations are at individual level. Robust standard errors are in parentheses (adjusted for clustering at year and sub-district levels). All estimations include individual characteristics (gender, age group, level of education, relationship to household head and marital status), 2009 sub-district ethnolinguistic fragmentation and an urban-rural variable. Violent events are identified at sub-district level. Significance levels: *** $\mathrm{p}<0.01, * * \mathrm{p}<0.05, * \mathrm{p}<0.1$.

Sources: GPS-SHaSA modules, EMOP, RGPH, ACLED. INSTAT-Mali, DIAL-IRD, ACLED. Authors' calculations.

take the value of 1 if corresponding to the option of interest and 0 for any other response option. The estimates reported in Table 7 confirm the signs of the effects of violent events on interpersonal trust in Mali. The low significance levels of the previous estimates can be explained by the almost null impact of conflict on extreme answers. Adults are not significantly more likely to be "not at all" or "very" trusting (line 1 and 4) in exposed sub-districts. By contrast, those who are more balanced display greater sensitivity to the occurrence of violence. The detailed estimations confirm the lower generalised trust as well as trust in persons with different political opinions and trust in foreigners (respectively columns 1, 6 and 7). Trust in family members (column 2) seems not as negatively affected as in baseline estimates when looking at the details. Although citizens trust less "somewhat" in their own family members, they trust more "very" much. The impact on negative levels of trust remains very close to zero when it comes to family members. Trust in neighbours (column 3) seems also to be very marginally affected by violence, as none of the options are affected significantly. In addition, the results support the negative effect of the Malian conflict on trust in other ethnic groups (column 4) and to a lesser extent trust in other linguistic groups (column 5). Indeed, although the least and most trustful individuals do not appear to be affected by violence occurrence, exposed adults are more likely to "not really" trust other ethnic groups by 5 percentage points, significantly at $10 \%$. At the same time, the likelihood of trusting "somewhat" also decreases. Distrust in those with a different political opinion is particularly and negatively affected by the occurrence of violence confirming the impact on association membership. These results support the weakening of bridging ties and withdrawal into one's own group. Trust in closely-related people is affected to a very marginal extent by conflict occurrence, which differs from trust in out-groups.

As with the regressions on participation in associations, there is a risk of endogeneity bias from omitted variables and reverse causality. First, omitted variable bias is partly addressed by the implementation of the baseline estimation with additional controls. The results are presented in online appendix Table B8. The decline in generalised trust remains consistent across the estimations. In addition, we follow Altonji et al. (2005) procedure to measure the relative size of unobservables to observables to explain away the effect of occurrence of violent events on interpersonal trust. According to the different measures of trust, 
Table 7: Detailed level of interpersonal trust and occurrence of violent events

\begin{tabular}{|c|c|c|c|c|c|c|c|}
\hline \multirow[b]{3}{*}{ Dependent variable: Level of trust } & \multirow{3}{*}{$\begin{array}{c}\begin{array}{c}\text { Generalised } \\
\text { trust }\end{array} \\
(1)\end{array}$} & \multicolumn{6}{|c|}{ Trust in: } \\
\hline & & Relatives & Neighbours & $\begin{array}{c}\text { Other } \\
\text { ethnic group }\end{array}$ & $\begin{array}{c}\text { Other } \\
\text { linguistic group }\end{array}$ & $\begin{array}{c}\text { Different } \\
\text { pol. opinion }\end{array}$ & $\begin{array}{c}\text { Other } \\
\text { nationality }\end{array}$ \\
\hline & & $(2)$ & (3) & (4) & $(5)$ & (6) & $(7)$ \\
\hline \multicolumn{8}{|c|}{ Variable of interest: Occurrence of violent events $(t-1)$} \\
\hline Not at all & $\begin{array}{c}0.0272^{*} \\
(0.0143)\end{array}$ & $\begin{array}{l}0.00351^{*} \\
(0.00180)\end{array}$ & $\begin{array}{l}-0.00288 \\
(0.00785)\end{array}$ & $\begin{array}{l}-0.0111 \\
(0.0112)\end{array}$ & $\begin{array}{r}-0.00232 \\
(0.0118)\end{array}$ & $\begin{array}{r}-0.00597 \\
(0.0149)\end{array}$ & $\begin{array}{c}0.0242 \\
(0.0249)\end{array}$ \\
\hline Not really & $\begin{array}{c}0.0843^{* * *} \\
(0.0281)\end{array}$ & $\begin{array}{l}0.0192^{* *} \\
(0.00956)\end{array}$ & $\begin{array}{l}-0.0161 \\
(0.0218)\end{array}$ & $\begin{array}{l}0.0508^{*} \\
(0.0273)\end{array}$ & $\begin{array}{c}0.0357 \\
(0.0280)\end{array}$ & $\begin{array}{c}0.0779 * * \\
(0.0325)\end{array}$ & $\begin{array}{c}0.0384 \\
(0.0304)\end{array}$ \\
\hline Somewhat & $\begin{array}{c}-0.122^{* * *} \\
(0.0339)\end{array}$ & $\begin{array}{l}-0.0655 \\
(0.0404)\end{array}$ & $\begin{array}{c}0.0342 \\
(0.0311)\end{array}$ & $\begin{array}{l}-0.0305 \\
(0.0285)\end{array}$ & $\begin{array}{l}-0.0251 \\
(0.0304)\end{array}$ & $\begin{array}{c}-0.0594^{* *} \\
(0.0287)\end{array}$ & $\begin{array}{l}-0.0497^{*} \\
(0.0268)\end{array}$ \\
\hline Very & $\begin{array}{c}0.0107 \\
(0.0315)\end{array}$ & $\begin{array}{c}0.0428 \\
(0.0409)\end{array}$ & $\begin{array}{l}-0.0152 \\
(0.0391)\end{array}$ & $\begin{array}{r}-0.00910 \\
(0.0265)\end{array}$ & $\begin{array}{r}-0.00826 \\
(0.0247)\end{array}$ & $\begin{array}{l}-0.0126 \\
(0.0251)\end{array}$ & $\begin{array}{l}-0.0128 \\
(0.0215)\end{array}$ \\
\hline
\end{tabular}

Note: Estimations are at individual level. Robust standard errors are in parentheses (adjusted for clustering at the year and sub-district levels). Each cell corresponds to one estimation. All estimations include individual characteristics (gender, age group, level of education, relationship to household head and marital status), 2009 sub-district ethnolinguistic fragmentation, an urban-rural variable, district dummies and year dummies. Violent events are identified at sub-district level. Significance levels: ${ }^{* * *} \mathrm{p}<0.01, * * \mathrm{p}<0.05, * \mathrm{p}<0.1$.

Sources: GPS-SHaSA modules, EMOP, RGPH, ACLED. INSTAT-Mali, DIAL-IRD, ACLED. Authors' calculations.

unobservables should be from 1 to 13 times larger than observables to null the effect of violence. ${ }^{39}$ These results suggest that omitted variable bias is unlikely. Second, as argued in sub-section 3.2, we cast doubt on reverse causality bias when it comes to interpersonal trust. Comparing trust between areas never affected and those only affected from 2014 (or 2015) onwards mitigates the risk of reverse causation, as no differences can be significantly identified ex-ante. To further address the issue, we apply the IV estimation method using the same instrument as in regressions on participation. The results for bivariate probit second-stage estimations are reported in appendix Table A7. They are consistent with baseline estimates: generalised trust and trust in out-groups decrease in areas exposed to violent events. The results are highly significant for generalised trust and significant at $10 \%$ for trust in persons with different political opinions and trust in foreigners. Trust in neighbours is positively but non-significantly affected by violence occurrence while trust in relatives decreases but the effect is now significant at $10 \%$. Overall, these results should be considered with caution, they remain relatively imprecise for the same reasons as for the IV estimations for participation in associations.

The argument of withdrawal into one's own group is additionally documented by the differentiation of fragmented areas from homogeneous areas. The results reported in Table 8 are, again, compelling. Generalised trust (column 1) in homogeneous areas (panel A) is not affected by the occurrence of violent events. The coefficient is very close to zero. The same holds for trust in closely- and weakly-related individuals. Trust in people with a different political opinion (column 6) even suggests a positive effect. However, in relatively fragmented areas (panel B), the likelihood of trusting most people decreases significantly by 11 percentage points when the adult has been exposed to violent events. In these heterogeneous areas, trust in relatives (column 2) remains constant, while people are more trusting of their neighbours (column 3). The negative impact of conflict-induced violence on trust in out-groups is confirmed, particularly for trust in people with a different political opinion (column 6). These latter results robustly support the exclusion process interpretation. They feed into the intuition suggested by an increase in participation mainly in family

\footnotetext{
${ }^{39}$ Following Oster (2019) procedure, unobservables should represent twice the size of observables for generalized trust and trust in relatives, at least the same size as observables for trust in persons with different political opinions, and half the size of observables for trust in foreigners to explain away the effect of violence.
} 
Table 8: Interpersonal trust and occurrence of violent events in fragmented areas

\begin{tabular}{|c|c|c|c|c|c|c|c|}
\hline & \multirow[b]{2}{*}{$\begin{array}{c}\text { Generalised } \\
\text { trust }\end{array}$} & \multicolumn{6}{|c|}{ Trust in: } \\
\hline & & Relatives & Neighbours & $\begin{array}{c}\text { Other } \\
\text { ethnic group }\end{array}$ & $\begin{array}{c}\text { Other } \\
\text { linguistic group }\end{array}$ & $\begin{array}{c}\text { Different } \\
\text { pol. opinion }\end{array}$ & $\begin{array}{c}\text { Other } \\
\text { nationality }\end{array}$ \\
\hline & (1) & $(2)$ & $(3)$ & $(4)$ & $(5)$ & (6) & (7) \\
\hline \multicolumn{8}{|c|}{ Panel A: Homogeneous sub-districts $($ EthnFrag $\leq 0.4)$} \\
\hline Occurrence of violent events $(t-1)$ & $\begin{array}{l}-0.0191 \\
(0.0631)\end{array}$ & $\begin{array}{c}0.0239 \\
(0.0228)\end{array}$ & $\begin{array}{c}0.0271 \\
(0.0389)\end{array}$ & $\begin{array}{c}-0.00799 \\
(0.0594)\end{array}$ & $\begin{array}{l}-0.0414 \\
(0.0586)\end{array}$ & $\begin{array}{c}0.0471 \\
(0.0642)\end{array}$ & $\begin{array}{r}-0.00504 \\
(0.0698)\end{array}$ \\
\hline Observations & 17,078 & 17,037 & 17,094 & 17,097 & 17,095 & 17,096 & 17,094 \\
\hline Adjusted $R^{2}$ & 0.109 & 0.131 & 0.0851 & 0.127 & 0.130 & 0.131 & 0.133 \\
\hline \multicolumn{8}{|c|}{ Panel B: Fragmented sub-districts (EthnFrag $>0.4)$} \\
\hline Occurrence of violent events $(t-1)$ & $\begin{array}{c}-0.111^{* * * *} \\
(0.0396)\end{array}$ & $\begin{array}{l}-0.00670 \\
(0.00761)\end{array}$ & $\begin{array}{c}0.0304 \\
(0.0279)\end{array}$ & $\begin{array}{l}-0.0413 \\
(0.0364)\end{array}$ & $\begin{array}{l}-0.0330 \\
(0.0362)\end{array}$ & $\begin{array}{c}-0.0928^{* *} \\
(0.0370)\end{array}$ & $\begin{array}{l}-0.0604 \\
(0.0403)\end{array}$ \\
\hline Observations & 25,858 & 25,777 & 25,893 & 25,899 & 25,900 & 25,899 & 25,872 \\
\hline Adjusted $R^{2}$ & 0.111 & 0.0253 & 0.0716 & 0.119 & 0.120 & 0.125 & 0.139 \\
\hline
\end{tabular}

Note: Estimations are at individual level. Robust standard errors are in parentheses (adjusted for clustering at year and sub-district levels). All estimations include individual characteristics (gender, age group, level of education, relationship to household head and marital status), 2009 sub-district ethnolinguistic fragmentation, an urban-rural variable, district dummies and year dummies. Violent events are identified at sub-district level. Significance levels: ${ }^{* * *} \mathrm{p}<0.01,{ }^{* *} \mathrm{p}<0.05,{ }^{*} \mathrm{p}<0.1$.

Sources: GPS-SHaSA modules, EMOP, RGPH, ACLED. INSTAT-Mali, DIAL-IRD, ACLED. Authors' calculations.

associations and political associations. Trust in distant people with whom individuals more probably share weak ties declines, while trust in close individuals remains at a very high level and potentially increases. This evidence suggests withdrawal into one's own group at the expense of out-groups in Mali. The decline in trust in those with different political opinions in exposed areas further supports the large increase in participation in political associations. Politically-related issues logically appear as an additional substantial breaking point in a crisis that is primarily based on competing political agendas. In conflict-affected areas, increased participation in associations not only reflects coping strategies, but is also the expression of a broader divide between groups. This latter phenomenon is likely to foster sectarianism.

\section{Conclusion}

Long-lasting resentment among northern Malian citizens and relative government withdrawal from the north triggered the 2012 outbreak of an armed conflict that spread throughout the entire country. This paper analyses the conflict's repercussions on social capital using first-hand, original and high-quality survey data merged with event location data. Participation increased by 7 to 14 percentage points in conflict-affected areas, overall. This result is robust to supplementary estimation methods: IV and DiD estimates. Selection into migration bias is also mitigated. A prima facie analysis of these results appears to yield a positive interpretation of the conflict's effects on social capital in the case of Mali. Social capital would thus appear to be a logical driver (at least partly) of the post-war long-term recovery of the most affected areas, as documented in the empirical literature.

Further analyses suggest rather the opposite interpretation in Mali. This increased participation is driven by a substantially higher involvement of adults in family and political associations. Family association membership is based on deepened kinship-based ties and Malian political associations are largely characterised by cronyism and simply serve as a springboard to reach the political sphere itself. Furthermore, the positive effect of violence on participation in ethnically heterogeneous areas is observed only for associations 
where membership is based on kinship. In contrast, participation in heterogeneously-composed associations decreases in fragmented areas affected by violent events. This is the case for the most popular associations, namely, local development associations. The latter are a necessary means to improve individual and local living conditions via better access to information and more efficient collective action. Hence, where associations tend to be more heterogeneous, conflict has the opposite effect: violence implies disengagement. The negative effect of the occurrence of violence on participation in heterogeneous associations makes even more sense in the light of the developments in interpersonal trust in affected areas. We find that trust in people from out-groups declines in the case of exposure to violence, while trust in close individuals remains at very high levels and even tends to increase.

Our paper provides new empirical evidence on how conflict impacts social capital. We find differentiated effects depending on the type of association and the level of ethnic fragmentation in the local area. We show that the distinction between bonding-type (inward-looking) and bridging-type (outward-looking) social capital is necessary to fully capture the effects of conflict. We provide evidence of an increased in-group bias in conflict-affected areas, whose existence has been deemed speculative to date (Bauer et al., 2016). Even though the study is context-specific, these findings cast doubt on the role attributed to social capital as a driver of post-war and post-conflict recovery.

Our analysis is not only a step forward for the literature, but more importantly, makes for a better understanding of the ongoing conflict in a country destabilised by jihadist activities presenting a real risk for the entire Sahelian region. The results shed light on a rather worrying impact of conflict on social capital in Mali. The weakening of bridging associations implying the corrosion of bridging ties could be socioeconomically detrimental. At the same time, the development of inward-looking, Olsonian associations is even more worrying since the shift in interactions from out-groups to in-groups suggests a deepening of the conflict into entrenched opposition between groups. This opposition is shaped by greater political opposition and kinship within communities and ethnic groups. Incentives to engage with others diminish as distrust and exclusion increase because of the conflict. Interpersonal exchanges between Malians and between groups could therefore be negatively impacted to an even greater extent. This would be a harbinger of the conflict having negative indirect impacts on economic and political development in the longer run. Our analysis aligns and agrees with some experts' views as to the need for suitable solutions to avoid the entrenchment of violent opposition in Mali (Guichaoua and Pellerin, 2017). Some solutions may be found in more inclusive governance policies, including better representativeness and incentives for ethnic mixing. Our study also suggests that particular attention should be paid to local associations representing "bridging-type" social capital in Mali. They could play a role in preventing a conflict trap whereby armed conflict aggravates social divisions which escalate the conflict. 


\section{Appendix A}

Table A1: Main variables of interest - Descriptive statistics

\begin{tabular}{|c|c|c|c|c|c|c|c|c|}
\hline & \multicolumn{2}{|c|}{2006} & \multicolumn{2}{|c|}{2014} & \multicolumn{2}{|c|}{2015} & \multicolumn{2}{|c|}{2016} \\
\hline & Mean & Std. Dev & Mean & Std. Dev & Mean & Std. Dev & Mean & Std. Dev \\
\hline \multicolumn{9}{|l|}{ Variables from survey data } \\
\hline \multicolumn{9}{|c|}{ Association participation (2006: participation at household level, individual level otherwise) } \\
\hline In at least one association & 0.66 & 0.47 & 0.58 & 0.49 & 0.52 & 0.50 & 0.54 & 0.50 \\
\hline In a family association & 0.31 & 0.46 & 0.20 & 0.40 & 0.18 & 0.38 & 0.20 & 0.40 \\
\hline In a political association & 0.24 & 0.43 & 0.17 & 0.38 & 0.13 & 0.33 & 0.24 & 0.43 \\
\hline In a professional association & 0.20 & 0.40 & 0.19 & 0.39 & 0.17 & 0.38 & 0.19 & 0.39 \\
\hline In a local association & 0.35 & 0.48 & 0.38 & 0.48 & 0.35 & 0.48 & 0.35 & 0.48 \\
\hline In a religious association & 0.26 & 0.44 & 0.14 & 0.35 & 0.12 & 0.33 & 0.12 & 0.32 \\
\hline \multicolumn{9}{|l|}{ Interpersonal trust } \\
\hline Generalised trust & $N / A$ & & 0.66 & 0.47 & 0.69 & 0.46 & 0.70 & 0.46 \\
\hline Trust in relatives & $N / A$ & & 0.96 & 0.20 & 0.90 & 0.30 & 0.95 & 0.21 \\
\hline Trust in neighbours & $N / A$ & & 0.79 & 0.41 & 0.75 & 0.43 & 0.81 & 0.39 \\
\hline Trust in person from a different ethnic group & $N / A$ & & 0.63 & 0.48 & 0.61 & 0.49 & 0.64 & 0.48 \\
\hline Trust in person speaking a different language & $N / A$ & & 0.60 & 0.49 & 0.59 & 0.49 & 0.62 & 0.48 \\
\hline Trust in person with a different political opinion & $N / A$ & & 0.57 & 0.49 & 0.58 & 0.49 & 0.62 & 0.49 \\
\hline Trust in person with a different nationality & $N / A$ & & 0.48 & 0.50 & 0.52 & 0.50 & 0.52 & 0.50 \\
\hline Scared of terrorist threat & $N / A$ & & 0.53 & 0.50 & 0.63 & 0.48 & 0.70 & 0.46 \\
\hline Scared of armed conflict/war threat & $N / A$ & & 0.54 & 0.50 & 0.59 & 0.49 & 0.59 & 0.49 \\
\hline Number of observations & 11,670 & & 13,835 & & 15,135 & & 14,335 & \\
\hline Treated $(t-1)$ & & & 0.22 & & 0.20 & & 0.31 & \\
\hline Treated $[2012 ;(t-1)]$ & & & 0.25 & & 0.31 & & 0.35 & \\
\hline Treated $[2006 ;(t-1)]$ & & & 0.28 & & 0.33 & & 0.38 & \\
\hline Number of households & 4,494 & & 5,214 & & 6,074 & & 5,881 & \\
\hline \multicolumn{9}{|l|}{ Event data variables (within Malian regions surveyed) } \\
\hline Violent events $(t-1)(a)$ & 0.00 & 0.00 & 0.24 & 1.50 & 0.12 & 0.90 & 0.31 & 1.37 \\
\hline$[\operatorname{Min} ; \operatorname{Max}]$ & {$[0 ; 0]$} & & {$[0 ; 17]$} & & {$[0 ; 10]$} & & {$[0 ; 13]$} & \\
\hline Violent events $[2012 ;(t-1)]^{(a)}$ & & & 0.38 & 2.19 & 1.20 & 7.78 & 1.58 & 9.28 \\
\hline$[\operatorname{Min} ; \operatorname{Max}]$ & & & {$[0 ; 23]$} & & {$[0 ; 98]$} & & {$[0 ; 111]$} & \\
\hline Violent events $[2006 ;(t-1)]^{(a)}$ & & & 0.43 & 2.37 & 1.32 & 8.42 & 1.70 & 9.95 \\
\hline$[\operatorname{Min} ; \operatorname{Max}]$ & & & {$[0 ; 26]$} & & {$[0 ; 101]$} & & {$[0 ; 114]$} & \\
\hline Fatalities $(t-1){ }^{(a)}$ & 0.00 & 0.00 & 1.03 & 9.90 & 0.24 & 2.08 & 0.79 & 3.70 \\
\hline$[\operatorname{Min} ; \operatorname{Max}]$ & {$[0 ; 0]$} & & {$[0 ; 140]$} & & {$[0 ; 28]$} & & {$[0 ; 32]$} & \\
\hline Fatalities $[2012 ;(t-1)]^{(a)}$ & & & 1.17 & 10.24 & 3.07 & 21.33 & 4.09 & 24.84 \\
\hline$[\operatorname{Min} ; \operatorname{Max}]$ & & & {$[0 ; 140]$} & & {$[0 ; 263]$} & & {$[0 ; 295]$} & \\
\hline Fatalities $[2006 ;(t-1)]{ }^{(a)}$ & & & 1.29 & 10.32 & 3.26 & 22.28 & 4.05 & 25.83 \\
\hline$[\operatorname{Min} ; \operatorname{Max}]$ & & & {$[0 ; 140]$} & & {$[0 ; 266]$} & & {$[0 ; 298]$} & \\
\hline
\end{tabular}

Note: ${ }^{(a)}$ per sub-district. Weighted survey data.

Sources: GPS-SHaSA modules, EMOP, ELIM, RGPH, ACLED. INSTAT-Mali, DIAL-IRD, ACLED. Authors' calculations.

\section{Appendix B}


Figure A1: Malian administrative divisions

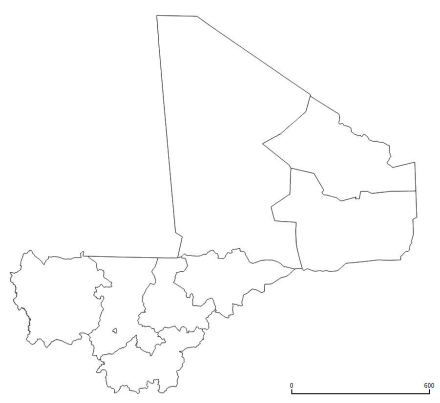

(a) 9 regions

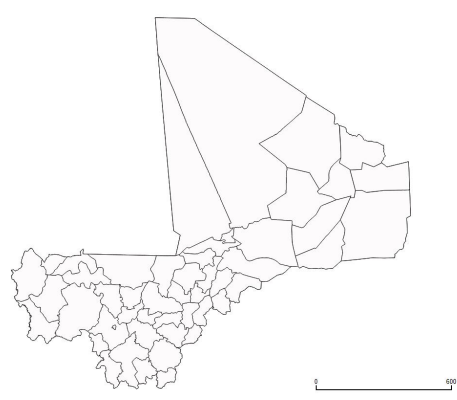

(b) 49 districts

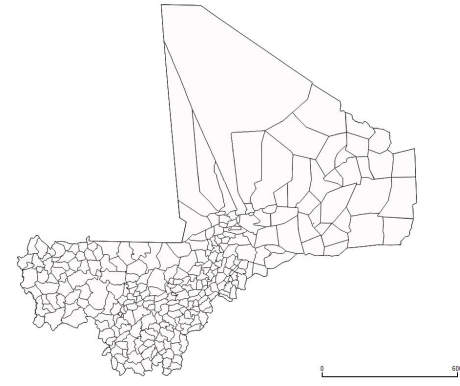

(c) 302 sub-districts

Table A2: Other control variables - Descriptive statistics

\begin{tabular}{|c|c|c|c|c|c|c|c|c|}
\hline & \multicolumn{2}{|c|}{2006} & \multicolumn{2}{|c|}{2014} & \multicolumn{2}{|c|}{2015} & \multicolumn{2}{|c|}{2016} \\
\hline & Mean & Std. Dev & Mean & Std. Dev & Mean & Std. Dev & Mean & Std. Dev \\
\hline \multicolumn{9}{|l|}{ Variables from survey data } \\
\hline Female & 0.54 & 0.50 & 0.53 & 0.50 & 0.54 & 0.50 & 0.52 & 0.50 \\
\hline Rural & 0.64 & 0.48 & 0.68 & 0.47 & 0.73 & 0.44 & 0.74 & 0.44 \\
\hline \multicolumn{9}{|l|}{ Level of education reached } \\
\hline No education & 0.78 & 0.41 & 0.68 & 0.46 & 0.74 & 0.44 & 0.72 & 0.45 \\
\hline Fondamental I & 0.09 & 0.29 & 0.16 & 0.37 & 0.12 & 0.32 & 0.13 & 0.33 \\
\hline Fondamental II & 0.06 & 0.24 & 0.07 & 0.25 & 0.08 & 0.28 & 0.09 & 0.28 \\
\hline Secondary & 0.05 & 0.21 & 0.07 & 0.25 & 0.04 & 0.20 & 0.05 & 0.21 \\
\hline Post-Secondary & 0.02 & 0.13 & 0.02 & 0.15 & 0.02 & 0.14 & 0.02 & 0.13 \\
\hline Age & 37.72 & 14.83 & 38.06 & 15.85 & 38.76 & 15.53 & 38.77 & 15.13 \\
\hline \multicolumn{9}{|l|}{ Age group } \\
\hline $18-24$ у.о. & 0.20 & 0.40 & 0.22 & 0.41 & 0.20 & 0.40 & 0.19 & 0.39 \\
\hline $25-30$ y.о. & 0.19 & 0.40 & 0.20 & 0.40 & 0.19 & 0.39 & 0.20 & 0.40 \\
\hline $31-40$ y.о. & 0.25 & 0.43 & 0.22 & 0.41 & 0.23 & 0.42 & 0.23 & 0.42 \\
\hline $41-50$ y.о. & 0.17 & 0.38 & 0.15 & 0.35 & 0.15 & 0.36 & 0.17 & 0.37 \\
\hline $51-60$ y.о. & 0.08 & 0.28 & 0.09 & 0.28 & 0.10 & 0.30 & 0.10 & 0.30 \\
\hline 61 y.o. and more & 0.10 & 0.30 & 0.13 & 0.33 & 0.13 & 0.33 & 0.12 & 0.32 \\
\hline \multicolumn{9}{|l|}{ Relationship to household head } \\
\hline Head & 0.32 & 0.47 & 0.22 & 0.41 & 0.26 & 0.44 & 0.30 & 0.46 \\
\hline Spouse & 0.33 & 0.47 & 0.26 & 0.44 & 0.30 & 0.46 & 0.33 & 0.47 \\
\hline Child & 0.14 & 0.35 & 0.16 & 0.36 & 0.17 & 0.37 & 0.17 & 0.37 \\
\hline Other relatives & 0.19 & 0.39 & 0.34 & 0.48 & 0.25 & 0.44 & 0.20 & 0.40 \\
\hline Other unrelated members & 0.01 & 0.12 & 0.02 & 0.14 & 0.01 & 0.10 & 0.01 & 0.10 \\
\hline \multicolumn{9}{|l|}{ Marital status } \\
\hline Married (monogamous) & 0.54 & 0.50 & 0.47 & 0.50 & 0.47 & 0.50 & 0.51 & 0.50 \\
\hline Married (polygamous) & 0.23 & 0.42 & 0.29 & 0.45 & 0.31 & 0.46 & 0.30 & 0.46 \\
\hline Common law couple & 0.00 & 0.02 & 0.01 & 0.08 & 0.01 & 0.09 & 0.01 & 0.08 \\
\hline Single & 0.16 & 0.36 & 0.17 & 0.38 & 0.15 & 0.35 & 0.13 & 0.34 \\
\hline Divorced/Separated & 0.01 & 0.11 & 0.01 & 0.08 & 0.01 & 0.10 & 0.00 & 0.06 \\
\hline Widow & 0.06 & 0.25 & 0.06 & 0.23 & 0.05 & 0.23 & 0.05 & 0.21 \\
\hline 2009 census data & & & & Mean & Std. Dev. & & & \\
\hline Ethnolinguistic fragmentation (per commune) & & & & 0.39 & 0.20 & & & \\
\hline Ethnolinguistic fragmentation (per sub-district) & & & & 0.41 & 0.19 & & & \\
\hline
\end{tabular}

Note: Weighted survey data.

Sources: GPS-SHaSA modules, EMOP, ELIM, RGPH. INSTAT-Mali, DIAL-IRD. Authors' calculations. 
Table A3: Participation in associations, occurrence of violent events and additional controls

\begin{tabular}{|c|c|c|c|c|c|c|c|}
\hline & \multicolumn{7}{|c|}{ Member of at least one association } \\
\hline & $(1)$ & $(2)$ & $(3)$ & $(4)$ & $(5)$ & $(6)$ & $(7)$ \\
\hline Occurrence of violent events $(t-1)$ & $\begin{array}{r}0.129^{* * *} \\
(0.0379)\end{array}$ & $\begin{array}{r}0.128^{* * *} \\
(0.0389)\end{array}$ & $\begin{array}{c}0.127^{* * *} \\
(0.0370)\end{array}$ & $\begin{array}{c}0.0957^{* * *} \\
(0.0265)\end{array}$ & $\begin{array}{r}0.129^{* * *} \\
(0.0376)\end{array}$ & $\begin{array}{r}0.131^{* * *} \\
(0.0371)\end{array}$ & $\begin{array}{c}0.127^{* * *} \\
(0.0362)\end{array}$ \\
\hline Std. dev. of rainfall from the $2005-2015$ average $(t-1)$ & $\begin{array}{r}-0.00243 \\
(0.0150)\end{array}$ & & & & & & $\begin{array}{r}-0.00222 \\
(0.0148)\end{array}$ \\
\hline Std. dev. of rainfall from the $2005-2015$ average $(t-2)$ & $\begin{array}{l}0.00932 \\
(0.0177)\end{array}$ & & & & & & $\begin{array}{l}0.00869 \\
(0.0173)\end{array}$ \\
\hline Distance to main roads (log) & $\begin{array}{c}0.00562 \\
(0.00631)\end{array}$ & & & & & & $\begin{array}{c}0.00659 \\
(0.00619)\end{array}$ \\
\hline \multicolumn{8}{|l|}{ Per capita consumption quintiles (ref. : First quintile) } \\
\hline Second & & $\begin{array}{r}-0.00625 \\
(0.0109)\end{array}$ & & & & & $\begin{array}{r}-0.00446 \\
(0.0108)\end{array}$ \\
\hline Third & & $\begin{array}{c}-0.0305^{* *} \\
(0.0126)\end{array}$ & & & & & $\begin{array}{c}-0.0320^{* * *} \\
(0.0124)\end{array}$ \\
\hline Fourth & & $\begin{array}{c}-0.0452^{* * *} \\
(0.0143)\end{array}$ & & & & & $\begin{array}{c}-0.0494^{* * *} \\
(0.0139)\end{array}$ \\
\hline Fifth & & $\begin{array}{c}-0.0490^{* * *} \\
(0.0158)\end{array}$ & & & & & $\begin{array}{c}-0.0571^{* * *} \\
(0.0153)\end{array}$ \\
\hline Scared of terrorist threat & & & $\begin{array}{c}0.0433^{* *} \\
(0.0175)\end{array}$ & & & & $\begin{array}{c}0.0450^{* * *} \\
(0.0173)\end{array}$ \\
\hline Scared of armed conflict threat & & & $\begin{array}{l}0.0333^{*} \\
(0.0177)\end{array}$ & & & & $\begin{array}{l}0.0307^{*} \\
(0.0172)\end{array}$ \\
\hline Sick/hurt the past 3 months $[2015 ; 2016]$ & & & & $\begin{array}{c}0.0145 \\
(0.00942)\end{array}$ & & & \\
\hline Local tensions $(t-1)$ & & & & & $\begin{array}{c}0.0201 \\
(0.0174)\end{array}$ & & $\begin{array}{c}0.0142 \\
(0.0174)\end{array}$ \\
\hline Access to the administration in general & & & & & & $\begin{array}{r}0.119^{* * *} \\
(0.0135)\end{array}$ & $\begin{array}{c}0.119^{* * *} \\
(0.0132)\end{array}$ \\
\hline Controls & YES & YES & YES & YES & YES & YES & YES \\
\hline District dummies & YES & YES & YES & YES & YES & YES & YES \\
\hline Year dummies & YES & YES & YES & YES & YES & YES & YES \\
\hline Observations & 42,967 & 42,908 & 42,943 & 29,469 & 42,925 & 42,939 & 42,825 \\
\hline Adjusted $R^{2}$ & 0.185 & 0.186 & 0.188 & 0.203 & 0.185 & 0.191 & 0.196 \\
\hline
\end{tabular}

Note: Estimations are at individual level. Robust standard errors are in parentheses (adjusted for clustering at year and sub-district levels). All estimations include individual characteristics (gender, age group, level of education, relationship to household head and marital status), 2009 sub-district ethnolinguistic fragmentation and urban-rural variable. Violent events are identified at sub-district level. Significance levels: *** $\mathrm{p}<0.01, * * \mathrm{p}<0.05, * \mathrm{p}<0.1$.

Sources: GPS-SHaSA modules, EMOP, RGPH, ACLED. INSTAT-Mali, DIAL-IRD, ACLED. Authors'calculations. 
Figure A2: 1997-2005 violent events and intensity

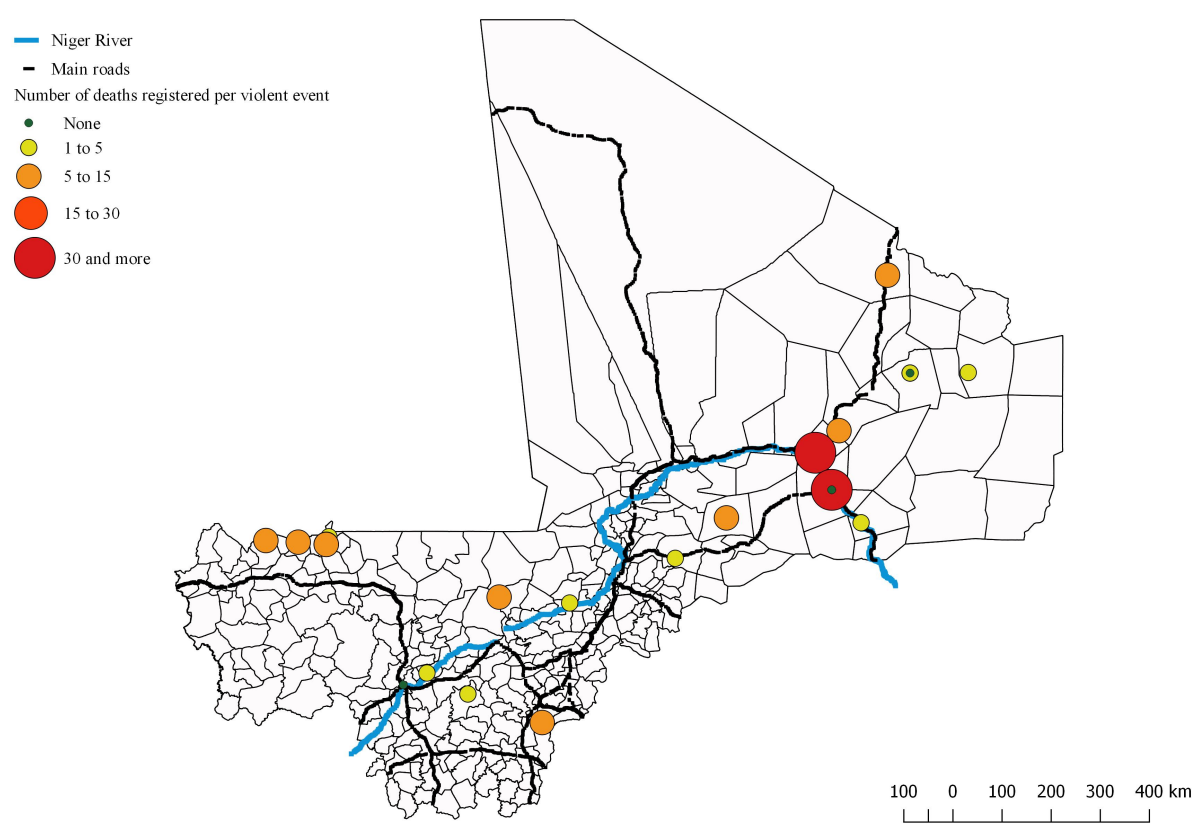

Sources: ACLED, GADM, authors' computation.

Table A4: Olsonian and Putnamesque participation and occurrence of violent events

\begin{tabular}{|c|c|c|c|c|c|c|}
\hline & \multicolumn{3}{|c|}{ Olsonian associations } & \multicolumn{3}{|c|}{ Putnamesque associations } \\
\hline & (1) & $(2)$ & $(3)$ & $(4)$ & $(5)$ & (6) \\
\hline Occurrence of violent events $(t-1)$ & $\begin{array}{l}0.132^{* * *} \\
(0.0425)\end{array}$ & $\begin{array}{l}0.471^{*} \\
(0.240)\end{array}$ & & $\begin{array}{c}0.0367 \\
(0.0344)\end{array}$ & $\begin{array}{c}-0.0666 \\
(0.165)\end{array}$ & \\
\hline Post-2012 dummy $\times$ Occurrence $[2006 ;(t-1)]$ & & & $\begin{array}{l}0.125^{* *} \\
(0.0632)\end{array}$ & & & $\begin{array}{c}0.0504 \\
(0.0574)\end{array}$ \\
\hline Std. dev. of rainfall $(t-1)$ & NO & YES & $\mathrm{NO}$ & NO & YES & $\mathrm{NO}$ \\
\hline Occurrence of violent events $[1997 ; 2005]$ & NO & YES & $\mathrm{NO}$ & NO & YES & NO \\
\hline Controls & YES & YES & YES & YES & YES & YES \\
\hline District dummies & YES & YES & YES & YES & YES & YES \\
\hline Year dummies & YES & YES & YES & YES & YES & YES \\
\hline Region $\times$ Post-2012 dummies & NO & NO & YES & $\mathrm{NO}$ & $\mathrm{NO}$ & YES \\
\hline Method & OLS & 2SLS & $\mathrm{DiD}$ & OLS & 2SLS & $\mathrm{DiD}$ \\
\hline Observations & 42,967 & 42,967 & 54,878 & 42,967 & 42,967 & 54,878 \\
\hline Adjusted $R^{2}$ & 0.181 & 0.163 & 0.130 & 0.158 & 0.156 & 0.156 \\
\hline
\end{tabular}

Note: Estimations are at individual level. Robust standard errors are in parentheses (adjusted for clustering at sub-district and year levels, and only for sub-district level for DiD estimations). Olsonian associations comprise family, political and professional associations. Putnamesque associations comprise local and religious associations. All estimations include individual characteristics (gender, age group, level of education, relationship to household head and marital status), 2009 sub-district ethnolinguistic fragmentation, an urban-rural variable, district dummies, year dummies and pre and post-treatment regional dummies. Violent events are identified at sub-district level. Significance levels: ${ }^{* * *} \mathrm{p}<0.01,{ }^{* *} \mathrm{p}<0.05,{ }^{*} \mathrm{p}<0.1$.

Sources: GPS-SHaSA modules, EMOP, ELIM, RGPH, ACLED. INSTAT-Mali, DIAL-IRD, ACLED. Authors' calculations. 
Table A5: Trends in membership and occurrence of violent events since 2014 or 2015

\begin{tabular}{|c|c|c|c|c|c|c|}
\hline & \multirow[b]{2}{*}{$\begin{array}{l}\text { At least one } \\
\text { association }\end{array}$} & \multicolumn{3}{|c|}{ Olsonian groups } & \multicolumn{2}{|c|}{ Putnamesque groups } \\
\hline & & $\begin{array}{c}\text { A family } \\
\text { association }\end{array}$ & $\begin{array}{l}\text { A political } \\
\text { association }\end{array}$ & $\begin{array}{l}\text { A professional } \\
\text { association }\end{array}$ & $\begin{array}{c}\text { A local } \\
\text { association }\end{array}$ & $\begin{array}{l}\text { A religious } \\
\text { association }\end{array}$ \\
\hline & $(1)$ & $(2)$ & (3) & $(4)$ & $(5)$ & (6) \\
\hline \multicolumn{7}{|l|}{ Panel A: Only 2006 and 2014 samples } \\
\hline 2014 dummy & $\begin{array}{c}0.228^{* * *} \\
(0.0618)\end{array}$ & $\begin{array}{c}0.0935 \\
(0.0755)\end{array}$ & $\begin{array}{c}0.0791 \\
(0.0625)\end{array}$ & $\begin{array}{l}0.00862 \\
(0.0600)\end{array}$ & $\begin{array}{c}0.316^{* * *} \\
(0.0472)\end{array}$ & $\begin{array}{l}-0.0778 \\
(0.0526)\end{array}$ \\
\hline Exposed only in 2014 or after & $\begin{array}{c}0.0335 \\
(0.0546)\end{array}$ & $\begin{array}{l}-0.0163 \\
(0.0561)\end{array}$ & $\begin{array}{c}0.0117 \\
(0.0617)\end{array}$ & $\begin{array}{c}0.0162 \\
(0.0509)\end{array}$ & $\begin{array}{l}-0.0899^{*} \\
(0.0528)\end{array}$ & $\begin{array}{l}-0.112^{* *} \\
(0.0487)\end{array}$ \\
\hline $2014 \times$ Exposed only in 2014 or after & $\begin{array}{l}-0.0852 \\
(0.0792)\end{array}$ & $\begin{array}{l}-0.0601 \\
(0.0909)\end{array}$ & $\begin{array}{c}-0.133 \\
(0.0931)\end{array}$ & $\begin{array}{l}-0.0761 \\
(0.0800)\end{array}$ & $\begin{array}{c}0.140^{*} \\
(0.0793)\end{array}$ & $\begin{array}{c}0.0976 \\
(0.0768)\end{array}$ \\
\hline Controls & YES & YES & YES & YES & YES & YES \\
\hline District dummies & YES & YES & YES & YES & YES & YES \\
\hline Year dummies & YES & YES & YES & YES & YES & YES \\
\hline Region $\times$ Post-2012 dummies & YES & YES & YES & YES & YES & YES \\
\hline Observations & 17,667 & 17,660 & 17,673 & 17,673 & 17,673 & 17,676 \\
\hline Adjusted $R^{2}$ & 0.0859 & 0.124 & 0.0988 & 0.120 & 0.110 & 0.0840 \\
\hline \multicolumn{7}{|l|}{ Panel B: 2006-2014-2015 samples } \\
\hline Post-2012 dummy & $\begin{array}{l}0.0831^{*} \\
(0.0484)\end{array}$ & $\begin{array}{l}-0.0332 \\
(0.0409)\end{array}$ & $\begin{array}{c}-0.133^{* * *} \\
(0.0375)\end{array}$ & $\begin{array}{c}0.0776^{* *} \\
(0.0377)\end{array}$ & $\begin{array}{c}0.215^{* * *} \\
(0.0770)\end{array}$ & $\begin{array}{c}-0.186^{* * *} \\
(0.0465)\end{array}$ \\
\hline Exposed only in 2015 or after & $\begin{array}{c}0.0771 \\
(0.0621)\end{array}$ & $\begin{array}{c}0.0560 \\
(0.0834)\end{array}$ & $\begin{array}{c}0.0493 \\
(0.0655)\end{array}$ & $\begin{array}{c}0.0811 \\
(0.0594)\end{array}$ & $\begin{array}{l}-0.0197 \\
(0.0631)\end{array}$ & $\begin{array}{l}-0.0425 \\
(0.0601)\end{array}$ \\
\hline Post- $2012 \times$ Exposed only in 2015 or after & $\begin{array}{l}-0.0643 \\
(0.0780)\end{array}$ & $\begin{array}{l}-0.109 \\
(0.108)\end{array}$ & $\begin{array}{l}-0.0821 \\
(0.0812)\end{array}$ & $\begin{array}{l}-0.0441 \\
(0.0681)\end{array}$ & $\begin{array}{c}0.0636 \\
(0.0851)\end{array}$ & $\begin{array}{c}0.0127 \\
(0.0806)\end{array}$ \\
\hline Controls & YES & YES & YES & YES & YES & YES \\
\hline District dummies & YES & YES & YES & YES & YES & YES \\
\hline Year dummies & YES & YES & YES & YES & YES & YES \\
\hline Region $\times$ Post-2012 dummies & YES & YES & YES & YES & YES & YES \\
\hline Observations & 27,582 & 27,575 & 27,588 & 27,588 & 27,588 & 27,591 \\
\hline Adjusted $R^{2}$ & 0.0922 & 0.118 & 0.101 & 0.123 & 0.0992 & 0.0827 \\
\hline
\end{tabular}

Note: Estimations are at individual level. Robust standard errors are in parentheses (adjusted for clustering at sub-district level). All estimations include individual characteristics (gender, age group, level of education, relationship to household head and marital status), 2009 sub-district ethnolinguistic fragmentation and an urban-rural variable. Violent events are identified at sub-district level. Significance levels: ${ }^{* * *} \mathrm{p}<0.01,{ }^{* *} \mathrm{p}<0.05,{ }^{*} \mathrm{p}<0.1$.

Sources: GPS-SHaSA modules, EMOP, ELIM, RGPH, ACLED. INSTAT-Mali, DIAL-IRD, ACLED. Authors' calculations. 
Table A6: Participation in associations of non-migrants and occurrence of violent events

\begin{tabular}{|c|c|c|c|c|c|c|}
\hline & \multirow[b]{2}{*}{$\begin{array}{l}\text { At least one } \\
\text { association }\end{array}$} & \multicolumn{3}{|c|}{ Olsonian groups } & \multicolumn{2}{|c|}{ Putnamesque groups } \\
\hline & & $\begin{array}{c}\text { A family } \\
\text { association }\end{array}$ & $\begin{array}{l}\text { A political } \\
\text { association }\end{array}$ & $\begin{array}{c}\text { A professional } \\
\text { association }\end{array}$ & $\begin{array}{c}\text { A local } \\
\text { association }\end{array}$ & $\begin{array}{l}\text { A religious } \\
\text { association }\end{array}$ \\
\hline & $(1)$ & $(2)$ & $(3)$ & $(4)$ & $(5)$ & $(6)$ \\
\hline \multicolumn{7}{|l|}{ Panel A: 2006 - 2015 unconstrained samples } \\
\hline 2015 dummy & $\begin{array}{r}-0.135^{* *} \\
(0.0671)\end{array}$ & $\begin{array}{l}-0.199 * * \\
(0.0859)\end{array}$ & $\begin{array}{c}-0.177^{* * *} \\
(0.0486)\end{array}$ & $\begin{array}{c}-0.149^{* * *} \\
(0.0573)\end{array}$ & $\begin{array}{l}-0.0310 \\
(0.0690)\end{array}$ & $\begin{array}{c}-0.0949^{*} \\
(0.0501)\end{array}$ \\
\hline Occurrence of violent events [2006; 2014] & $\begin{array}{c}0.0172 \\
(0.0451)\end{array}$ & $\begin{array}{l}-0.0691 \\
(0.0510)\end{array}$ & $\begin{array}{l}-0.0452 \\
(0.0397)\end{array}$ & $\begin{array}{l}-0.0479 \\
(0.0388)\end{array}$ & $\begin{array}{l}-0.0278 \\
(0.0448)\end{array}$ & $\begin{array}{l}-0.0261 \\
(0.0351)\end{array}$ \\
\hline $2015 \times$ Occurrence & $\begin{array}{c}0.0246 \\
(0.0671)\end{array}$ & $\begin{array}{c}0.127 \\
(0.0857)\end{array}$ & $\begin{array}{c}0.0821 * \\
(0.0484)\end{array}$ & $\begin{array}{c}0.103^{*} \\
(0.0577)\end{array}$ & $\begin{array}{c}0.0775 \\
(0.0693)\end{array}$ & $\begin{array}{c}0.0405 \\
(0.0499)\end{array}$ \\
\hline Observations & 26,740 & 26,726 & 26,725 & 26,730 & 26,733 & 26,734 \\
\hline Adjusted $R^{2}$ & 0.109 & 0.135 & 0.103 & 0.145 & 0.161 & 0.0915 \\
\hline \multicolumn{7}{|c|}{ Panel B: Adults who migrated in the past 10 years excluded from 2015 sample } \\
\hline 2015 dummy & $\begin{array}{c}-0.140^{* *} \\
(0.0667)\end{array}$ & $\begin{array}{c}-0.225^{* * *} \\
(0.0867)\end{array}$ & $\begin{array}{c}-0.170^{* * *} \\
(0.0452)\end{array}$ & $\begin{array}{c}-0.139^{* *} \\
(0.0582)\end{array}$ & $\begin{array}{l}-0.0231 \\
(0.0691)\end{array}$ & $\begin{array}{c}-0.0947^{*} \\
(0.0511)\end{array}$ \\
\hline Occurrence of violent events [2006;2014] & $\begin{array}{c}0.0146 \\
(0.0443)\end{array}$ & $\begin{array}{l}-0.0660 \\
(0.0481)\end{array}$ & $\begin{array}{l}-0.0460 \\
(0.0380)\end{array}$ & $\begin{array}{l}-0.0498 \\
(0.0380)\end{array}$ & $\begin{array}{l}-0.0318 \\
(0.0440)\end{array}$ & $\begin{array}{l}-0.0251 \\
(0.0342)\end{array}$ \\
\hline $2015 \times$ Occurrence & $\begin{array}{c}0.0204 \\
(0.0666)\end{array}$ & $\begin{array}{c}0.127 \\
(0.0864)\end{array}$ & $\begin{array}{c}0.0823^{*} \\
(0.0449)\end{array}$ & $\begin{array}{c}0.0958 \\
(0.0589)\end{array}$ & $\begin{array}{c}0.0850 \\
(0.0697)\end{array}$ & $\begin{array}{c}0.0474 \\
(0.0507)\end{array}$ \\
\hline Observations & 24,744 & 24,730 & 24,729 & 24,734 & 24,737 & 24,738 \\
\hline Adjusted $R^{2}$ & 0.105 & 0.140 & 0.0928 & 0.146 & 0.151 & 0.0919 \\
\hline
\end{tabular}

Note: Estimations are at individual level. Robust standard errors are in parentheses (adjusted for clustering at sub-district level). All estimations include individual characteristics (gender, age group, level of education, relationship to household head and marital status), 2009 sub-district ethnolinguistic fragmentation, urban-rural variable, district dummies and pre and post-treatment regional dummies. Violent events are identified at sub-district level. Significance levels: ${ }^{* * *} \mathrm{p}<0.01,{ }^{* *} \mathrm{p}<0.05,{ }^{*} \mathrm{p}<0.1$.

Sources: GPS-SHaSA modules, EMOP, ELIM, RGPH, ACLED. INSTAT-Mali, DIAL-IRD, ACLED. Authors'calculations.

Table A7: Interpersonal trust and occurrence of violent events (IV second stage - Bivariate probit)

\begin{tabular}{|c|c|c|c|c|c|c|c|}
\hline & \multirow[b]{2}{*}{$\begin{array}{c}\text { Generalised } \\
\text { trust }\end{array}$} & \multicolumn{6}{|c|}{ Trust in: } \\
\hline & & Relatives & Neighbours & $\begin{array}{c}\text { Other } \\
\text { ethnic group }\end{array}$ & $\begin{array}{c}\text { Other } \\
\text { linguistic group }\end{array}$ & $\begin{array}{c}\text { Different } \\
\text { pol. opinion }\end{array}$ & $\begin{array}{c}\text { Other } \\
\text { nationality }\end{array}$ \\
\hline & (1) & $(2)$ & (3) & (4) & (5) & (6) & (7) \\
\hline Occurrence of violent events $(t-1)$ & $\begin{array}{c}-0.255^{* * *} \\
(0.0674)\end{array}$ & $\begin{array}{c}-0.0473^{*} \\
(0.0262)\end{array}$ & $\begin{array}{c}0.0575 \\
(0.0589)\end{array}$ & $\begin{array}{l}-0.0918 \\
(0.0752)\end{array}$ & $\begin{array}{l}-0.0855 \\
(0.0758)\end{array}$ & $\begin{array}{l}-0.155^{*} \\
(0.0803)\end{array}$ & $\begin{array}{l}-0.183^{*} \\
(0.0952)\end{array}$ \\
\hline Std. dev. of rainfall & YES & YES & YES & YES & YES & YES & YES \\
\hline Occurrence of violent events $[1997 ; 2005]$ & YES & YES & YES & YES & YES & YES & YES \\
\hline Controls & YES & YES & YES & YES & YES & YES & YES \\
\hline District dummies & YES & YES & YES & YES & YES & YES & YES \\
\hline Year dummies & YES & YES & YES & YES & YES & YES & YES \\
\hline Observations & 42,936 & 42,814 & 42,987 & 42,996 & 42,995 & 42,995 & 42,966 \\
\hline
\end{tabular}

Note: Marginal effects estimated at individual level. Robust standard errors are in parentheses (adjusted for clustering at sub-district and year levels). All estimations include individual characteristics (gender, age group, level of education, relationship to household head and marital status), 2009 sub-district ethnolinguistic fragmentation, urban-rural variable, district dummies and pre and post-treatment regional dummies. Violent events are identified at sub-district level. Significance levels: ${ }^{* * *} \mathrm{p}<0.01,{ }^{* *} \mathrm{p}<0.05,{ }^{*} \mathrm{p}<0.1$.

Sources: GPS-SHaSA modules, EMOP, ELIM, RGPH, ACLED. INSTAT-Mali, DIAL-IRD, ACLED. Authors'calculations. 
Figure B1: Fear of armed conflict threat per district and recorded violent events

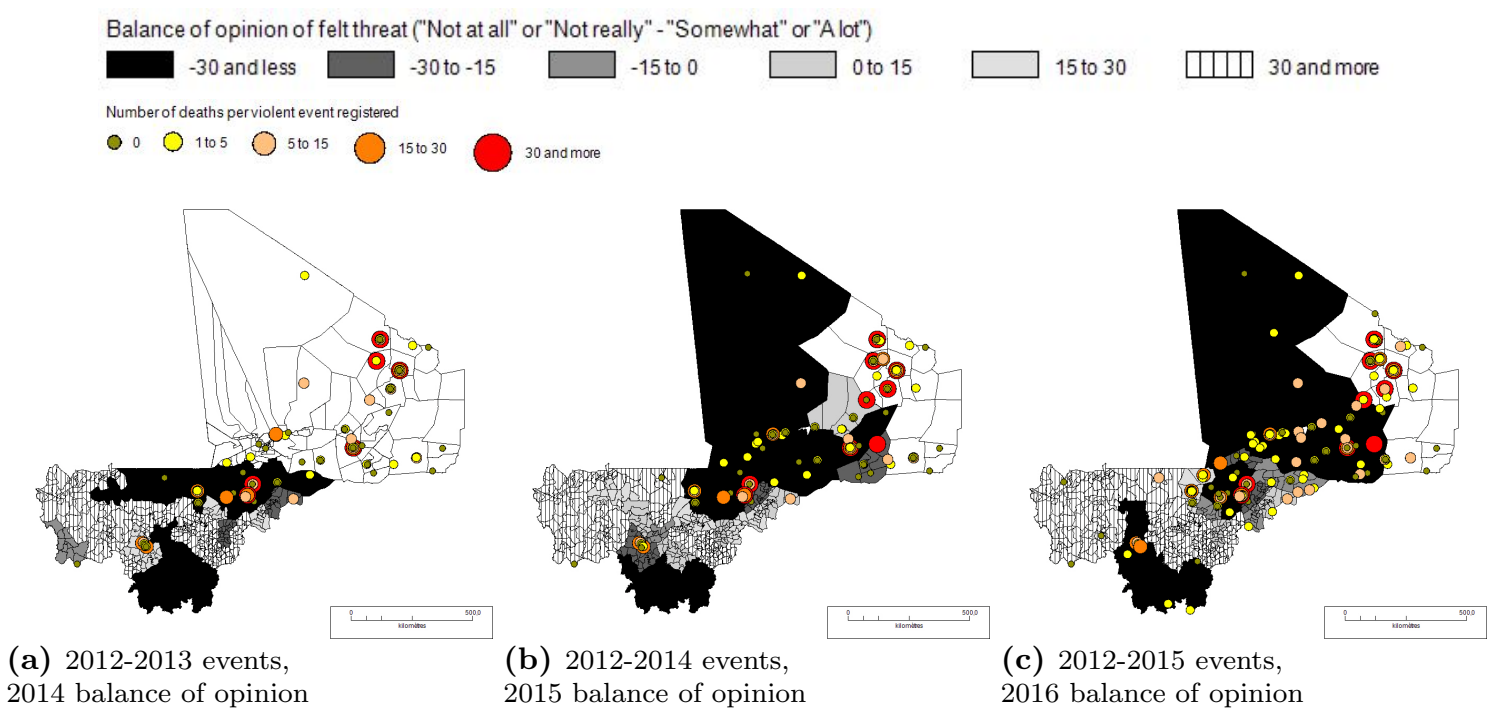

Note: White backdrop corresponds to non-surveyed districts.

Sources: GPS-SHaSA modules, EMOP, ACLED. INSTAT-Mali, DIAL-IRD, ACLED. Authors' computation.

Figure B2: Communes ethno-linguistic fragmentation and 2012-2015 violent events

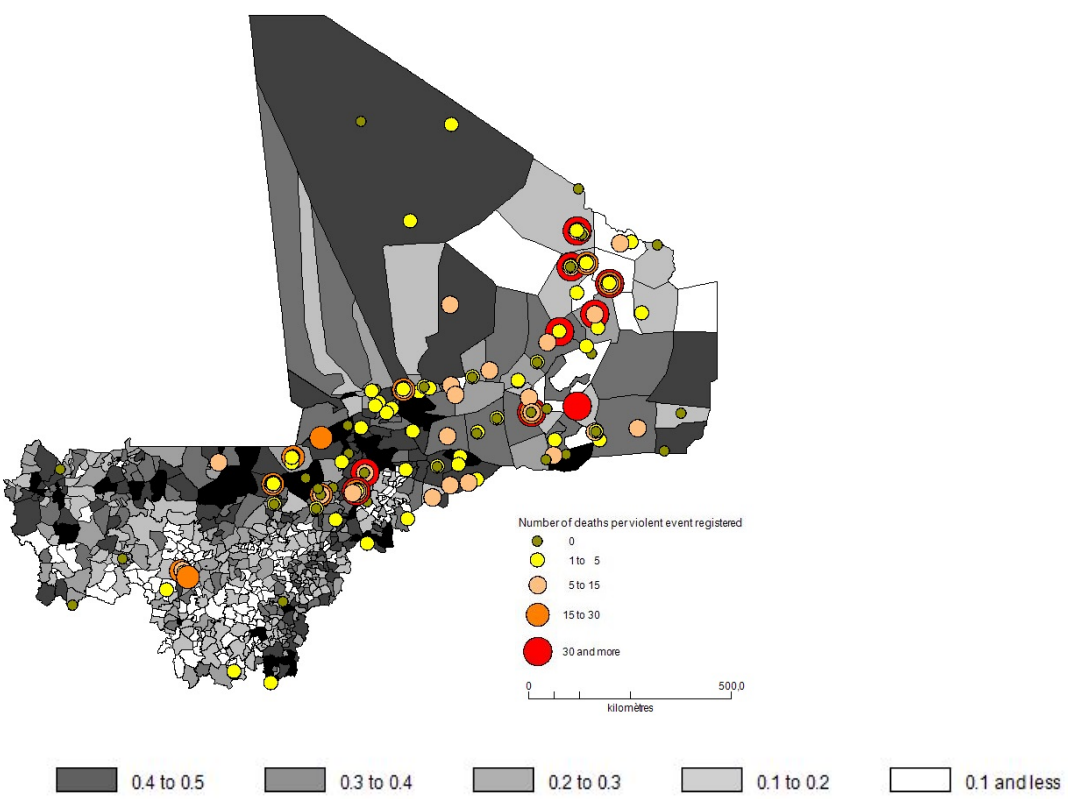

Sources: ACLED, GPS-SHaSA modules, EMOP. INSTAT-Mali, DIAL-IRD, ACLED. Authors' computation. 
Table B1: Benchmark results: determinants of participation in associations

\begin{tabular}{|c|c|c|c|c|c|c|}
\hline & $\begin{array}{l}\text { At least one } \\
\text { association }\end{array}$ & $\begin{array}{c}\text { A family } \\
\text { association }\end{array}$ & $\begin{array}{l}\text { A political } \\
\text { association } \\
\end{array}$ & $\begin{array}{c}\text { A professional } \\
\text { association }\end{array}$ & $\begin{array}{c}\text { A local } \\
\text { association } \\
\end{array}$ & $\begin{array}{l}\text { A religious } \\
\text { association }\end{array}$ \\
\hline & $(1)$ & $(2)$ & $(3)$ & $(4)$ & $(5)$ & $(6)$ \\
\hline Female & $\begin{array}{c}-0.0521^{* * *} \\
(0.00860)\end{array}$ & $\begin{array}{c}0.0329 * * * \\
(0.00666)\end{array}$ & $\begin{array}{c}-0.0662^{* * *} \\
(0.00653)\end{array}$ & $\begin{array}{c}-0.0755^{* * *} \\
(0.00635)\end{array}$ & $\begin{array}{c}-0.0360 * * * \\
(0.00785)\end{array}$ & $\begin{array}{l}-0.0111^{* *} \\
(0.00523)\end{array}$ \\
\hline Rural & $\begin{array}{c}0.0937^{* * * *} \\
(0.0106)\end{array}$ & $\begin{array}{c}0.00145 \\
(0.00929)\end{array}$ & $\begin{array}{l}-0.00593 \\
(0.00852)\end{array}$ & $\begin{array}{l}0.0535 * * * \\
(0.00872)\end{array}$ & $\begin{array}{l}0.146^{* * *} \\
(0.0108)\end{array}$ & $\begin{array}{l}-0.00599 \\
(0.00721)\end{array}$ \\
\hline \multicolumn{7}{|l|}{ Age group - Reference: $31-40$} \\
\hline $18-24$ & $\begin{array}{c}-0.0817^{* * *} \\
(0.00809)\end{array}$ & $\begin{array}{c}-0.0230 * * * \\
(0.00664)\end{array}$ & $\begin{array}{c}-0.0424^{* * *} \\
(0.00623)\end{array}$ & $\begin{array}{c}-0.0403^{* * *} \\
(0.00633)\end{array}$ & $\begin{array}{c}-0.0519 * * * \\
(0.00764)\end{array}$ & $\begin{array}{c}-0.0140 * * * \\
(0.00475)\end{array}$ \\
\hline $25-30$ & $\begin{array}{c}-0.0256^{* * *} \\
(0.00674)\end{array}$ & $\begin{array}{l}-0.00646 \\
(0.00574)\end{array}$ & $\begin{array}{l}-0.0105 * * \\
(0.00535)\end{array}$ & $\begin{array}{c}-0.0188^{* * *} \\
(0.00554)\end{array}$ & $\begin{array}{l}-0.0125^{*} \\
(0.00655)\end{array}$ & $\begin{array}{l}-0.00336 \\
(0.00431)\end{array}$ \\
\hline $41-50$ & $\begin{array}{c}0.00116 \\
(0.00681)\end{array}$ & $\begin{array}{l}-0.00315 \\
(0.00579)\end{array}$ & $\begin{array}{c}0.00515 \\
(0.00557)\end{array}$ & $\begin{array}{c}0.00430 \\
(0.00600)\end{array}$ & $\begin{array}{l}-0.000129 \\
(0.00666)\end{array}$ & $\begin{array}{c}0.0201^{* * * *} \\
(0.00488)\end{array}$ \\
\hline $51-60$ & $\begin{array}{l}1.76 \mathrm{e}-05 \\
(0.00880)\end{array}$ & $\begin{array}{l}-0.00807 \\
(0.00719)\end{array}$ & $\begin{array}{c}0.00337 \\
(0.00716)\end{array}$ & $\begin{array}{l}-0.0161^{* *} \\
(0.00774)\end{array}$ & $\begin{array}{c}0.0143 \\
(0.00876)\end{array}$ & $\begin{array}{c}0.0419^{* * *} \\
(0.00658)\end{array}$ \\
\hline 61 and older & $\begin{array}{c}-0.0715^{* * *} \\
(0.00951)\end{array}$ & $\begin{array}{c}-0.0237^{* * *} \\
(0.00740)\end{array}$ & $\begin{array}{c}-0.0557^{* * *} \\
(0.00699)\end{array}$ & $\begin{array}{c}-0.0930^{* * *} \\
(0.00751)\end{array}$ & $\begin{array}{c}-0.0429 * * * \\
(0.00921)\end{array}$ & $\begin{array}{c}0.0858^{* * * *} \\
(0.00749)\end{array}$ \\
\hline \multicolumn{7}{|c|}{ Level of education reached - Ref.: None } \\
\hline Fondamental I & $\begin{array}{c}0.0354 * * * \\
(0.00725)\end{array}$ & $\begin{array}{c}0.0165^{* * *} \\
(0.00615)\end{array}$ & $\begin{array}{c}0.0310^{* * *} \\
(0.00587)\end{array}$ & $\begin{array}{c}0.0317^{* * *} \\
(0.00606)\end{array}$ & $\begin{array}{l}0.0153^{* *} \\
(0.00705)\end{array}$ & $\begin{array}{l}0.0101^{* *} \\
(0.00485)\end{array}$ \\
\hline Fondamental II & $\begin{array}{c}0.0312^{* * *} \\
(0.00915)\end{array}$ & $\begin{array}{l}0.0159^{* *} \\
(0.00760)\end{array}$ & $\begin{array}{c}0.0582^{* * *} \\
(0.00750)\end{array}$ & $\begin{array}{l}0.0178^{* *} \\
(0.00712)\end{array}$ & $\begin{array}{c}-0.0277^{* * *} \\
(0.00825)\end{array}$ & $\begin{array}{c}0.00432 \\
(0.00601)\end{array}$ \\
\hline Secondary & $\begin{array}{c}0.0581^{* * *} \\
(0.0118)\end{array}$ & $\begin{array}{l}0.0239^{* *} \\
(0.00933)\end{array}$ & $\begin{array}{l}0.105^{* * *} \\
(0.00956)\end{array}$ & $\begin{array}{l}0.0736^{* * * *} \\
(0.00937)\end{array}$ & $\begin{array}{l}-0.0188^{*} \\
(0.00966)\end{array}$ & $\begin{array}{l}-0.00659 \\
(0.00717)\end{array}$ \\
\hline Post-secondary & $\begin{array}{c}0.109 * * * \\
(0.0176)\end{array}$ & $\begin{array}{c}0.0362^{* *} \\
(0.0147)\end{array}$ & $\begin{array}{c}0.106 * * * \\
(0.0143)\end{array}$ & $\begin{array}{c}0.0922^{* * *} \\
(0.0151)\end{array}$ & $\begin{array}{c}-0.00735 \\
(0.0143)\end{array}$ & $\begin{array}{l}-0.00613 \\
(0.0109)\end{array}$ \\
\hline \multicolumn{7}{|c|}{ Marital status - Ref.: Married - monogamous } \\
\hline Married - polygamous & $\begin{array}{c}0.0429 * * * \\
(0.00678)\end{array}$ & $\begin{array}{c}0.00517 \\
(0.00605)\end{array}$ & $\begin{array}{l}0.0127^{* *} \\
(0.00565)\end{array}$ & $\begin{array}{c}0.0234^{* * *} \\
(0.00543)\end{array}$ & $\begin{array}{c}0.0414 * * * \\
(0.00693)\end{array}$ & $\begin{array}{l}0.0107 * * \\
(0.00487)\end{array}$ \\
\hline Common law couple & $\begin{array}{l}0.278^{* * *} \\
(0.0426)\end{array}$ & $\begin{array}{c}0.157^{* * *} \\
(0.0370)\end{array}$ & $\begin{array}{l}-0.0173 \\
(0.0168)\end{array}$ & $\begin{array}{l}0.0442^{*} \\
(0.0241)\end{array}$ & $\begin{array}{c}0.225^{* * *} \\
(0.0385)\end{array}$ & $\begin{array}{c}0.114^{* * *} \\
(0.0354)\end{array}$ \\
\hline Single & $\begin{array}{c}-0.0688^{* * *} \\
(0.0101)\end{array}$ & $\begin{array}{c}-0.0306 * * * \\
(0.00793)\end{array}$ & $\begin{array}{c}-0.0372^{* * *} \\
(0.00788)\end{array}$ & $\begin{array}{c}-0.0744^{* * *} \\
(0.00788)\end{array}$ & $\begin{array}{c}-0.0481^{* * *} \\
(0.00928)\end{array}$ & $\begin{array}{c}-0.0220^{* * *} \\
(0.00606)\end{array}$ \\
\hline Divorced/Separated & $\begin{array}{c}-0.0770 * * * \\
(0.0278)\end{array}$ & $\begin{array}{l}-0.0198 \\
(0.0213)\end{array}$ & $\begin{array}{l}-0.0239 \\
(0.0206)\end{array}$ & $\begin{array}{c}-0.0428^{* *} \\
(0.0199)\end{array}$ & $\begin{array}{c}-0.0656^{* * *} \\
(0.0216)\end{array}$ & $\begin{array}{c}-0.0649 * * * \\
(0.0125)\end{array}$ \\
\hline Widow & $\begin{array}{c}-0.0659^{* * *} \\
(0.0129)\end{array}$ & $\begin{array}{l}-0.0161 \\
(0.0102)\end{array}$ & $\begin{array}{c}-0.0289^{* * *} \\
(0.00880)\end{array}$ & $\begin{array}{c}-0.0317^{* * *} \\
(0.00917)\end{array}$ & $\begin{array}{c}-0.0656^{* * *} \\
(0.0117)\end{array}$ & $\begin{array}{c}-0.0324^{* * *} \\
(0.00892)\end{array}$ \\
\hline \multicolumn{7}{|c|}{ Relationship to household head - Ref.: Head } \\
\hline Spouse & $\begin{array}{c}-0.0560 * * * \\
(0.00917)\end{array}$ & $\begin{array}{c}-0.0255^{* * *} \\
(0.00703)\end{array}$ & $\begin{array}{c}-0.0272^{* * *} \\
(0.00696)\end{array}$ & $\begin{array}{c}-0.0865^{* * *} \\
(0.00698)\end{array}$ & $\begin{array}{c}-0.0112 \\
(0.00832)\end{array}$ & $\begin{array}{c}-0.0392 * * * \\
(0.00582)\end{array}$ \\
\hline Child & $\begin{array}{c}0.00171 \\
(0.00996)\end{array}$ & $\begin{array}{c}-0.0260 * * * \\
(0.00801)\end{array}$ & $\begin{array}{l}0.0214^{* *} \\
(0.00843)\end{array}$ & $\begin{array}{c}-0.0405^{* * *} \\
(0.00849)\end{array}$ & $\begin{array}{c}0.0672^{* * *} \\
(0.00979)\end{array}$ & $\begin{array}{l}-0.0162^{* *} \\
(0.00652)\end{array}$ \\
\hline Other relatives & $\begin{array}{l}-0.0190 * * \\
(0.00897)\end{array}$ & $\begin{array}{c}-0.0250 * * * \\
(0.00707)\end{array}$ & $\begin{array}{l}-0.00331 \\
(0.00698)\end{array}$ & $\begin{array}{c}-0.0431^{* * *} \\
(0.00720)\end{array}$ & $\begin{array}{c}0.0313^{* * *} \\
(0.00855)\end{array}$ & $\begin{array}{c}-0.0253^{* * *} \\
(0.00602)\end{array}$ \\
\hline Unrelated & $\begin{array}{c}-0.116^{* * *} \\
(0.0267)\end{array}$ & $\begin{array}{c}-0.0843^{* * *} \\
(0.0144)\end{array}$ & $\begin{array}{c}-0.0474^{* * *} \\
(0.0173)\end{array}$ & $\begin{array}{c}-0.0683^{* * *} \\
(0.0218)\end{array}$ & $\begin{array}{l}-0.0269 \\
(0.0249)\end{array}$ & $\begin{array}{c}-0.0357^{* *} \\
(0.0144)\end{array}$ \\
\hline Ethnolinguistic fragmentation & $\begin{array}{c}0.0121 \\
(0.0299)\end{array}$ & $\begin{array}{l}-0.0310 \\
(0.0257)\end{array}$ & $\begin{array}{l}-0.0146 \\
(0.0235)\end{array}$ & $\begin{array}{c}0.0366 \\
(0.0245)\end{array}$ & $\begin{array}{l}-0.0598 \\
(0.0297)\end{array}$ & $\begin{array}{c}0.0299 \\
(0.0172)\end{array}$ \\
\hline District dummies & YES & YES & YES & YES & YES & YES \\
\hline Year dummies & YES & YES & YES & YES & YES & YES \\
\hline Observations & 42,967 & 42,967 & 42,992 & 42,995 & 42,993 & 42,993 \\
\hline Adjusted $R^{2}$ & 0.182 & 0.165 & 0.164 & 0.147 & 0.160 & 0.119 \\
\hline
\end{tabular}

Note: Estimations are at individual level. Robust standard errors in parentheses (adjusted for clustering at year and EA levels). Significance levels: $* * * \mathrm{p}<0.01, * * \mathrm{p}<0.05, * \mathrm{p}<0.1$

Sources: GPS-SHaSA modules, EMOP, RGPH, ACLED. INSTAT-Mali, DIAL-IRD, ACLED. Authors' calculations. 
Table B2: 2006 participation and ex-post occurrence of violent events

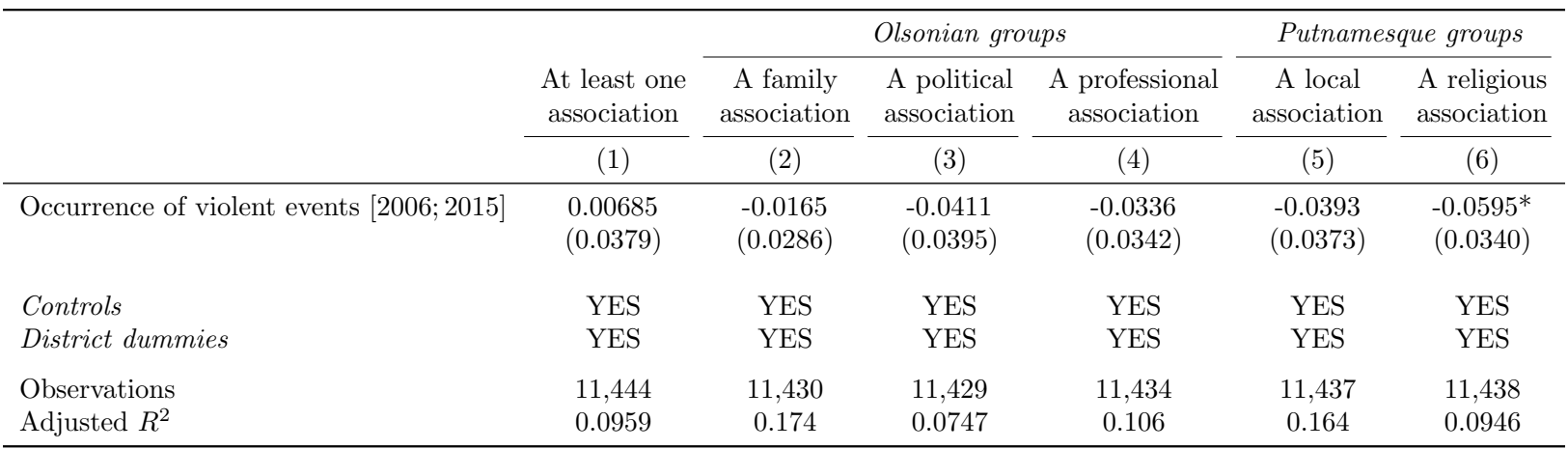

Note: Estimations are at individual level. Robust standard errors are in parentheses (adjusted for clustering at sub-district level). All estimations include individual characteristics (gender, age group, level of education, relationship to household head and marital status), 2009 sub-district ethnolinguistic fragmentation and urban-rural variable. Violent events are identified at sub-district level. Significance levels: $* * * \mathrm{p}<0.01,{ }^{* *} \mathrm{p}<0.05,{ }^{*} \mathrm{p}<0.1$.

Sources: ELIM, RGPH, ACLED. INSTAT-Mali, DIAL-IRD, ACLED. Authors'calculations.

Table B3: Participation and number, intensity and occurrence of violent events

\begin{tabular}{|c|c|c|c|c|c|c|}
\hline & \multicolumn{6}{|c|}{ Member of at least one association } \\
\hline & (1) & $(2)$ & $(3)$ & (4) & $(5)$ & (6) \\
\hline Number of violent events $[2012 ;(t-1)]$ & $\begin{array}{c}0.000365 \\
(0.000463)\end{array}$ & & & & & \\
\hline Number of violent events $[(t-2) ;(t-1)]$ & & $\begin{array}{c}-0.000983 \\
(0.00134)\end{array}$ & & & & \\
\hline Number of violent events $(t-1)$ & & & $\begin{array}{c}0.00420 \\
(0.00769)\end{array}$ & $\begin{array}{c}0.0559 * * \\
(0.0222)\end{array}$ & & \\
\hline (Number of violent events) $)^{2}(t-1)$ & & & & $\begin{array}{c}-0.00440 * * * \\
(0.00159)\end{array}$ & & \\
\hline Occurrence of violent events $[2012 ;(t-1)]$ & & & & & $\begin{array}{c}0.0792^{* * *} \\
(0.0267)\end{array}$ & \\
\hline Occurrence of violent events $[(t-2) ;(t-1)]$ & & & & & & $\begin{array}{c}0.0972 * * \\
(0.0392)\end{array}$ \\
\hline Controls & YES & YES & YES & YES & YES & YES \\
\hline District dummies & YES & YES & YES & YES & YES & YES \\
\hline Year dummies & YES & YES & YES & YES & YES & YES \\
\hline Observations & 42,967 & 42,967 & 42,967 & 42,967 & 42,967 & 42,967 \\
\hline Adjusted $R^{2}$ & 0.182 & 0.182 & 0.182 & 0.185 & 0.183 & 0.184 \\
\hline
\end{tabular}

Note: Estimations are at individual level. Robust standard errors are in parentheses (adjusted for clustering at sub-district level except columns 3 and 4 adjusted for clustering at year and sub-district levels). All estimations include individual characteristics (gender, age group, level of education, relationship to household head and marital status), 2009 sub-district ethnolinguistic fragmentation and urban-rural variable. Violent events are identified at sub-district level. Significance levels: *** $\mathrm{p}<0.01,{ }^{* *} \mathrm{p}<0.05,{ }^{*} \mathrm{p}<0.1$.

Sources: GPS-SHaSA modules, EMOP, RGPH, ACLED. INSTAT-Mali, DIAL-IRD, ACLED. Authors'calculations.

Abadie, A., Gardeazabal, J., 2003. The Economic Costs of Conflict: A Case Study of the Basque Country. American Economic Review 93 (1), 113-132.

Acemoglu, D., Robinson, J. A., 2008. Persistence of Power, Elites, and Institutions. American Economic Review 98 (1), $267-293$. Alesina, A., Giuliano, P., 2014. Family Ties. In: Aghion, P., Durlauf, S. N. (Eds.), Handbook of Economic Growth. Vol. 2 of Handbook of Economic Growth. Elsevier, Ch. 4, pp. 177-215.

Alesina, A., La Ferrara, E., 2000. Participation in Heterogeneous Communities. The Quarterly Journal of Economics 115 (3), 
Table B4: Participation and occurrence of violent events (alternative specifications)

\begin{tabular}{|c|c|c|c|c|c|}
\hline & \multicolumn{5}{|c|}{ Member of at least one association } \\
\hline & \multirow[b]{2}{*}{$(1)$} & \multirow[b]{2}{*}{$(2)$} & \multirow[b]{2}{*}{$(3)$} & hh. measure & Comm. geoloc. \\
\hline & & & & $(4)$ & $(5)$ \\
\hline Occurrence of violent events $(t-1)$ & $\begin{array}{c}0.0836 * * \\
(0.0373)\end{array}$ & $\begin{array}{c}0.129^{* * * *} \\
(0.0381)\end{array}$ & $\begin{array}{c}0.135^{* * *} \\
(0.0383)\end{array}$ & $\begin{array}{c}0.129 * * * \\
(0.0338)\end{array}$ & $\begin{array}{c}0.150^{* * * *} \\
(0.0401)\end{array}$ \\
\hline Controls & $\mathrm{NO}$ & YES & YES & YES & YES \\
\hline District dummies & YES & YES & YES & YES & YES \\
\hline Year dummies & YES & YES & YES & YES & YES \\
\hline Method & OLS & OLS & $\begin{array}{c}\text { Logit } \\
\text { (marg. eff.) }\end{array}$ & OLS & OLS \\
\hline Observations & 42,970 & 42,967 & 42,967 & 43,273 & 42,967 \\
\hline Adjusted $R^{2}$ & 0.154 & 0.185 & $\mathrm{~N} / \mathrm{A}$ & 0.171 & 0.185 \\
\hline Pseudo $R^{2}$ & $\mathrm{~N} / \mathrm{A}$ & $\mathrm{N} / \mathrm{A}$ & 0.147 & $\mathrm{~N} / \mathrm{A}$ & $\mathrm{N} / \mathrm{A}$ \\
\hline
\end{tabular}

Note: Estimations are at the individual level. Robust standard errors are in parentheses (adjusted for clustering at the year and sub-district levels). All estimations include individual characteristics (gender, age group, level of education, relationship to household head and marital status), 2009 sub-district ethno-linguistic fragmentation and an urban-rural variable. Events are identified at the sub-district level (except column 5 - which is identified at the commune level). Significance levels: $* * * \mathrm{p}<0.01$, $* * \mathrm{p}<0.05, * \mathrm{p}<0.1$.

Sources: GPS-SHaSA modules, EMOP, RGPH, ACLED. INSTAT-Mali, DIAL-IRD, ACLED. Authors' calculations.

Table B5: Participation and occurrence of violent events excluding the North

\begin{tabular}{|c|c|c|c|c|c|c|}
\hline & \multirow[b]{2}{*}{$\begin{array}{l}\text { At least one } \\
\text { association }\end{array}$} & \multicolumn{3}{|c|}{ Olsonian groups } & \multicolumn{2}{|c|}{ Putnamesque groups } \\
\hline & & $\begin{array}{l}\text { A family } \\
\text { association }\end{array}$ & $\begin{array}{l}\text { A political } \\
\text { association }\end{array}$ & $\begin{array}{l}\text { A professional } \\
\text { association }\end{array}$ & $\begin{array}{c}\text { A local } \\
\text { association }\end{array}$ & $\begin{array}{l}\text { A religious } \\
\text { association }\end{array}$ \\
\hline & (1) & $(2)$ & (3) & (4) & (5) & (6) \\
\hline Occurrence of violent events $(t-1)$ & $\begin{array}{c}0.153^{* * *} \\
(0.0478)\end{array}$ & $\begin{array}{c}0.0553 \\
(0.0439)\end{array}$ & $\begin{array}{c}0.128^{* * *} \\
(0.0485)\end{array}$ & $\begin{array}{c}0.0351 \\
(0.0402)\end{array}$ & $\begin{array}{c}0.0322 \\
(0.0404)\end{array}$ & $\begin{array}{c}0.0281 \\
(0.0285)\end{array}$ \\
\hline Controls & YES & YES & YES & YES & YES & YES \\
\hline District dummies & YES & YES & YES & YES & YES & YES \\
\hline Year dummies & YES & YES & YES & YES & YES & YES \\
\hline Observations & 39,427 & 39,427 & 39,452 & 39,455 & 39,453 & 39,453 \\
\hline Adjusted $R^{2}$ & 0.172 & 0.0931 & 0.138 & 0.124 & 0.146 & 0.0819 \\
\hline
\end{tabular}

Note: Estimations are at the individual level. Robust standard errors are in parentheses (adjusted for clustering at the year and sub-district levels). All estimations include individual characteristics (gender, age group, level of education, relationship to household head and marital status), 2009 sub-district ethno-linguistic fragmentation and an urban-rural variable. Events are identified at the sub-district level (except column 5 - which is identified at the commune level). Significance levels: $* * * \mathrm{p}<0.01,{ }^{*} \mathrm{p}<0.05,{ }^{*} \mathrm{p}<0.1$.

Sources: GPS-SHaSA modules, EMOP, RGPH, ACLED. INSTAT-Mali, DIAL-IRD, ACLED. Authors' calculations.

$847-904$.

Altonji, J. G., Elder, T. E., Taber, C. R., 2005. Selection on Observed and Unobserved Variables: Assessing the Effectiveness of Catholic Schools. Journal of Political Economy 113 (1), 151-184.

Anderson, T. W., Rubin, H., 1949. Estimation of the Parameters of a Single Equation in a Complete System of Stochastic Equations. The Annals of Mathematical Statistics 20 (1), 46-63.

Angrist, J. D., Kugler, A. D., 2008. Rural Windfall or a New Resource Curse? Coca, Income, and Civil Conflict in Colombia. The Review of Economics and Statistics 90 (2), 191-215.

Angrist, J. D., Pischke, J.-S., 2009. Mostly Harmless Econometrics: An Empiricist's Companion. Princeton University Press, Princeton. 
Table B6: Summary of placebo tests of difference-in-differences estimations

\begin{tabular}{|c|c|c|c|c|c|c|}
\hline & \multirow[b]{2}{*}{$\begin{array}{l}\text { At least one } \\
\text { association }\end{array}$} & \multicolumn{3}{|c|}{ Olsonian groups } & \multicolumn{2}{|c|}{ Putnamesque groups } \\
\hline & & $\begin{array}{c}\text { A family } \\
\text { association }\end{array}$ & $\begin{array}{l}\text { A political } \\
\text { association }\end{array}$ & $\begin{array}{l}\text { A professional } \\
\text { association }\end{array}$ & $\begin{array}{c}\text { A local } \\
\text { association }\end{array}$ & $\begin{array}{l}\text { A religious } \\
\text { association }\end{array}$ \\
\hline & (1) & $(2)$ & (3) & (4) & (5) & (6) \\
\hline \multicolumn{7}{|c|}{ Placebo treatment (500 iterations) - actual outcomes } \\
\hline Share of positive results significant at $10 \%$ & $4.6 \%$ & $6.0 \%$ & $4.4 \%$ & $5.0 \%$ & $8.8 \%$ & $4.8 \%$ \\
\hline \multicolumn{7}{|c|}{ Actual treatment - placebo outcomes (500 iterations) } \\
\hline Share of positive results significant at $10 \%$ & $7.0 \%$ & $6.8 \%$ & $6.0 \%$ & $7.8 \%$ & $8.2 \%$ & $5.8 \%$ \\
\hline
\end{tabular}

Table B7: Interpersonal trust and occurrence of violent events (alternative specifications)

\begin{tabular}{|c|c|c|c|c|c|c|}
\hline & \multicolumn{6}{|c|}{ Generalized trust } \\
\hline & & & & & Comm. geoloc. & North excluded \\
\hline & $(1)$ & $(2)$ & $(3)$ & $(4)$ & $(5)$ & (6) \\
\hline Occurrence of violent events $(t-1)$ & $\begin{array}{c}-0.0572^{* *} \\
(0.0273)\end{array}$ & $\begin{array}{c}-0.136^{* * *} \\
(0.0363)\end{array}$ & $\begin{array}{c}-0.111^{* * *} \\
(0.0360)\end{array}$ & $\begin{array}{c}-0.116^{* * * *} \\
(0.0348)\end{array}$ & $\begin{array}{c}-0.115^{* * *} \\
(0.0386)\end{array}$ & $\begin{array}{c}-0.134^{* * *} \\
(0.0407)\end{array}$ \\
\hline Controls & NO & NO & YES & YES & YES & YES \\
\hline District dummies & $\mathrm{NO}$ & YES & YES & YES & YES & YES \\
\hline Year dummies & NO & YES & YES & YES & YES & YES \\
\hline Method & OLS & OLS & OLS & $\begin{array}{c}\text { Logit } \\
\text { (marg. eff.) }\end{array}$ & OLS & OLS \\
\hline Observations & 42,939 & 42,939 & 42,936 & 42,936 & 42,936 & 39,396 \\
\hline Adjusted $R^{2}$ & 0.00280 & 0.101 & 0.105 & $\mathrm{~N} / \mathrm{A}$ & 0.105 & 0.103 \\
\hline Pseudo $R^{2}$ & $\mathrm{~N} / \mathrm{A}$ & $\mathrm{N} / \mathrm{A}$ & $\mathrm{N} / \mathrm{A}$ & 0.0914 & $\mathrm{~N} / \mathrm{A}$ & $\mathrm{N} / \mathrm{A}$ \\
\hline
\end{tabular}

Note: Estimations are at the individual level. Robust standard errors are in parentheses (adjusted for clustering at the year and sub-district levels). All estimations include individual characteristics (gender, age group, level of education, relationship to household head and marital status), 2009 sub-district ethno-linguistic fragmentation and an urban-rural variable. Events are identified at the sub-district level (except column 5 - which is identified at the commune level). Significance levels: $* * * \mathrm{p}<0.01,{ }^{*} \mathrm{p}<0.05,{ }^{*} \mathrm{p}<0.1$.

Sources: GPS-SHaSA modules, EMOP, RGPH, ACLED. INSTAT-Mali, DIAL-IRD, ACLED. Authors' calculations.

Bauer, M., Blattman, C., Chytilovà, J., Henrich, J., Miguel, E., Mitts, T., 2016. Can War Foster Cooperation? Journal of Economic Perspectives 30 (3), 249-274.

Bauer, M., Cassar, A., Chytilovà, J., Henrich, J., 2014. War's Enduring Effects on the Development of Egalitarian Motivations and In-Group Biases. Psychological Science 25 (1), 47-57.

Bellows, J., Miguel, E., 2006. War and Institutions: New Evidence from Sierra Leone. American Economic Review 96 (2), 394-399.

Bellows, J., Miguel, E., 2009. War and local collective action in Sierra Leone. Journal of Public Economics 93 (11), $1144-1157$. Berman, N., Couttenier, M., Rohner, D., Thoenig, M., 2017. This Mine Is Mine! How Minerals Fuel Conflicts in Africa. American Economic Review 107 (6), 1564-1610.

Blattman, C., 2009. From Violence to Voting: War and Political Participation in Uganda. American Political Science Review 103 (2), 231-247.

Bouju, J., 2000. Clientélisme, corruption et gouvernance locale à Mopti (Mali). Autrepart 14, 143-163, [In French].

Bourdieu, P., 1980. Le capital social. Actes de la recherche en sciences sociales 31 (1), 2-3, [In French].

Bowles, S., 2009. Did Warfare Among Ancestral Hunter-Gatherers Affect the Evolution of Human Social Behaviors? Science 324 (5932), 1293-1298.

Brakman, S., Garretsen, H., Schramm, M., 2004. The strategic bombing of German cities during World War II and its impact on city growth. Journal of Economic Geography 4 (2), 201-218. 
Table B8: Interpersonal trust, occurrence of violent events and additional controls

\begin{tabular}{|c|c|c|c|c|c|c|c|}
\hline & \multicolumn{7}{|c|}{ Generalized trust } \\
\hline & (1) & $(2)$ & (3) & $(4)$ & $(5)$ & $(6)$ & (7) \\
\hline Occurrence of violent events $(t-1)$ & $\begin{array}{c}-0.115^{* * *} \\
(0.0377)\end{array}$ & $\begin{array}{c}-0.113^{* * *} \\
(0.0357)\end{array}$ & $\begin{array}{c}-0.112^{* * *} \\
(0.0361)\end{array}$ & $\begin{array}{c}-0.110^{* * *} \\
(0.0347)\end{array}$ & $\begin{array}{c}-0.0751^{* * *} \\
(0.0258)\end{array}$ & $\begin{array}{c}-0.111^{* * *} \\
(0.0360)\end{array}$ & $\begin{array}{c}-0.115^{* * *} \\
(0.0361)\end{array}$ \\
\hline Std. dev. of rainfall from the $2005-2015$ average $(t-1)$ & $\begin{array}{c}-0.0641^{* * *} \\
(0.0142)\end{array}$ & & & & & & $\begin{array}{c}-0.0645^{* * *} \\
(0.0140)\end{array}$ \\
\hline Std. dev. of rainfall from the $2005-2015$ average $(t-2)$ & $\begin{array}{c}-0.0485^{* * *} \\
(0.0168)\end{array}$ & & & & & & $\begin{array}{c}-0.0466^{* * *} \\
(0.0165)\end{array}$ \\
\hline Distance to main roads (log) & $\begin{array}{l}0.0180^{* *} \\
(0.00836)\end{array}$ & & & & & & $\begin{array}{l}0.0179^{* *} \\
(0.00829)\end{array}$ \\
\hline Per capita consumption quintile (ref. : First quintile & & & & & & & \\
\hline Second & & $\begin{array}{l}-0.0101 \\
(0.0113)\end{array}$ & & & & & $\begin{array}{r}-0.00703 \\
(0.0111)\end{array}$ \\
\hline Third & & $\begin{array}{l}-0.0248^{*} \\
(0.0147)\end{array}$ & & & & & $\begin{array}{l}-0.0214 \\
(0.0146)\end{array}$ \\
\hline Fourth & & $\begin{array}{c}-0.0518^{* * *} \\
(0.0163)\end{array}$ & & & & & $\begin{array}{c}-0.0478^{* * *} \\
(0.0161)\end{array}$ \\
\hline Fifth & & $\begin{array}{c}-0.0517^{* * *} \\
(0.0179)\end{array}$ & & & & & $\begin{array}{c}-0.0477^{* * *} \\
(0.0179)\end{array}$ \\
\hline Scared of terrorist threat & & & $\begin{array}{c}0.0124 \\
(0.0249)\end{array}$ & & & & $\begin{array}{c}0.0158 \\
(0.0248)\end{array}$ \\
\hline Scared of armed conflict threat & & & $\begin{array}{c}0.00938 \\
(0.0208)\end{array}$ & & & & $\begin{array}{c}0.0163 \\
(0.0206)\end{array}$ \\
\hline Local tensions $(t-1)$ & & & & $\begin{array}{c}-0.0806^{* * *} \\
(0.0221)\end{array}$ & & & $\begin{array}{c}-0.0843^{* * *} \\
(0.0228)\end{array}$ \\
\hline Sick/hurt the past 3 months $[2015 ; 2016]$ & & & & & $\begin{array}{l}-0.0285 \\
(0.0234)\end{array}$ & & \\
\hline Access to the administration in general & & & & & & $\begin{array}{l}0.00111 \\
(0.0145)\end{array}$ & $\begin{array}{l}0.00103 \\
(0.0142)\end{array}$ \\
\hline Controls & YES & YES & YES & YES & YES & YES & YES \\
\hline District dummies & YES & YES & YES & YES & YES & YES & YES \\
\hline Year dummies & YES & YES & YES & YES & YES & YES & YES \\
\hline Observations & 42,936 & 42,881 & 42,915 & 42,905 & 29,463 & 42,904 & 42,801 \\
\hline Adjusted $R^{2} 0.109$ & 0.106 & 0.105 & 0.107 & 0.136 & 0.105 & 0.113 & \\
\hline
\end{tabular}

Note: Estimations are at individual level. Robust standard errors are in parentheses (adjusted for clustering at year and sub-district levels). All estimations include individual characteristics (gender, age group, level of education, relationship to household head and marital status), 2009 subdistrict ethno-linguistic fragmentation and urban-rural variable. Violent events are identified at sub-district level. Significance levels: $* * * \quad \mathrm{p}<0.01$, $* * \mathrm{p}<0.05,{ }^{*} \mathrm{p}<0.1$.

Sources: GPS-SHaSA modules, EMOP, ELIM, RGPH, ACLED. INSTAT-Mali, DIAL-IRD, ACLED. Authors'calculations.

Burt, R. S., 2001. Structural Holes versus Network Closure as Social Capital. In: Lin, N., Cook, K., Burt, R. S. (Eds.), Social Capital: Theory and Research. Routledge, New York, NY, Ch. 2, pp. 31-56.

Carmil, D., Breznitz, S., 1991. Personal trauma and world view-Are extremely stressful experiences related to political attitudes, religious beliefs, and future orientation? Journal of Traumatic Stress 4 (3), 393-405.

Cassar, A., Grosjean, P., Whitt, S., 2013. Legacies of violence: trust and market development. Journal of Economic Growth $18(3), 285-318$.

Chauvet, L., Gubert, F., Mercier, M., Mesplé-Somps, S., 2015. Migrants' home town associations and local development in Mali. The Scandinavian Journal of Economics 117 (2), 686-722.

Chauzal, G., 2007. Mali : les recettes d'une démocratisation réussie. Alternatives Internationales - Alternatives économiques 3 (34), 16, [In French].

Chauzal, G., van Damme, T., 2015. The roots of Mali's conflict. Tech. rep., Clingendael Netherlands Institute of International Relations, Conflict Research Unit.

Chiburis, R. C., Das, J., Lokshin, M., 2012. A practical comparison of the bivariate probit and linear IV estimators. Economics Letters 117 (3), 762-766.

Choi, J.-K., Bowles, S., 2007. The Coevolution of Parochial Altruism and War. Science 318 (5850), 636-640.

Colletta, N. J., Cullen, M. L., 2000. Violent conflict and the transformation of social capital: Lessons from Cambodia, Rwanda, Guatemala, and Somalia. The World Bank.

Collier, P., Elliot, V. L., Hegre, H., Hoeffler, A., Reynal-Querol, M., Sambanis, N., 2003. Breaking the Conflict Trap: Civil 
War and Development Policy. World Bank and Oxford University Press, Washington D.C.

Couttenier, M., Soubeyran, R., 2014. Drought and Civil War In Sub-Saharan Africa. The Economic Journal 124 (575), 201-244.

Couttenier, M., Soubeyran, R., 2015. A Survey of the Causes of Civil Conflicts: Natural Factors and Economic Conditions. Revue d'économie politique 125 (6), 787-810.

Croicu, M., Sundberg, R., 2015. UCDP GED Codebook version 2.0. Department of Peace and Conflict Research, Uppsala University, Uppsala, Sweden.

Davis, D. R., Weinstein, D. E., 2002. Bones, Bombs, and Break Points: The Geography of Economic Activity. American Economic Review 92 (5), 1269-1289.

De Luca, G., Verpoorten, M., 2011. From vice to virtue? Civil war and social capital in Uganda. LICOS Discussion Paper 298. De Luca, G., Verpoorten, M., 2015. Civil war, social capital and resilience in Uganda. Oxford Economic Papers 67 (3), $661-386$. de Montclos, M.-A. P., Minor, E., Sinha, S. (Eds.), 2016. Violence, Statistics, and the Politics of Accounting for the Dead. Demographic Transformation and Socio-Economic Development. Springer International Publishing.

Djankov, S., Glaeser, E., La Porta, R., Lopez-de-Silanes, F., Shleifer, A., 2003. The new comparative economics. Journal of Comparative Economics 31 (4), 595-619.

Durlauf, S. N., Fafchamps, M., 2005. Social Capital. In: Aghion, P., Durlauf, S. N. (Eds.), Handbook of Economic Growth. Vol. 1B. Elsevier, Netherlands, Ch. 26, pp. 1639-1699.

Dyregrov, A., Gjestad, R., Raundalen, M., 2002. Children exposed to warfare: A longitudinal study. Journal of Traumatic Stress $15(1), 59-68$.

Fidrmuc, J., Gërxhani, K., 2008. Mind the gap! Social capital, East and West. Journal of Comparative Economics 36 (2), 264-286.

Gaibulloev, K., Sandler, T., 2009. The Impact of Terrorism and Conflicts on Growth in Asia. Economics and Politics 21 (3), 359-383.

Galy, M. (Ed.), 2013. La guerre au Mali: comprendre la crise au Sahel et au Sahara: enjeux et zones d'ombre. Cahiers Libres. La Découverte, [In French].

Gilligan, M. J., Pasquale, B. J., Samii, C., 2014. Civil war and social cohesion: Lab-in-the-field evidence from Nepal. American Journal of Political Science 58 (3), 604-619.

Government of Mali, 2015. Accord Pour La Paix Et La Réconciliation Au Mali Issu Du Processus D'Alger. [in french].

Granovetter, M. S., 1973. The Strength of Weak Ties. American Journal of Sociology 78 (6), 1360-1380.

Grosjean, P., 2014. Conflict and Social and Political Preferences: Evidence from World War II and Civil Conflict in 35 European Countries. Comparative Economic Studies 56 (3), 424-451.

Guichaoua, Y., Pellerin, M., 2017. Faire la paix et construire l'État : Les relations entre pouvoir central et périphéries sahéliennes au Niger et au Mali. Tech. Rep. 51, IRSEM, [In French].

Haddad, L., Maluccio, J. A., 2003. Trust, Membership in Groups, and Household Welfare: Evidence from KwaZulu-Natal, South Africa. Economic Development and Cultural Change 51 (3), 573-601.

Harari, M., La Ferrara, E., 2018. Conflict, Climate, and Cells: A Disaggregated Analysis. The Review of Economics and Statistics 100 (4), 594-608.

Holder, G., Saint-Lary, M., 2013. Enjeux démocratiques et (re)conquête du politique en Afrique. De l'espace public religieux à l'émergence d'une sphère islamique oppositionnelle. Cahiers Sens public 15-16 (1), 187-205, [In French].

Hsiang, S. M., Burke, M., Miguel, E., 2013. Quantifying the influence of climate on human conflict. Science 341 (6151).

International Institute of Social Sciences, 2010. Indices of social development. URL: http://www.IndSocDev.org/.

International Organization for Migration (IOM), 2014a. Matrice de suivi des déplacements : Mali (Février 2014). [In French]. International Organization for Migration (IOM), 2014b. Matrice de suivi des déplacements : Mali (Décembre 2014). [In French].

Jackson, M. O., Rodriguez-Barraquer, T., Tan, X., 2012. Social Capital and Social Quilts: Network Patterns of Favor Exchange. American Economic Review 102 (5), 1857-1897.

Jennings, C., Sanchez-Pages, S., 2017. Social capital, conflict and welfare. Journal of Development Economics 124, $157-167$.

Jones, S. G., Muñoz, A., 2010. Afghanistan's Local War: Building Local Defense Forces. Rand National Defense Research.

Julien, S., 2011. Le Sahel comme espace de transit des stupéfiants. Acteurs et conséquences politiques. Hérodote (3), 125-142, [In French].

Knack, S., Keefer, P., 1997. Does Social Capital Have an Economic Payoff? A Cross-Country Investigation. The Quarterly Journal of Economics 112 (4), 1251-1288.

Koubi, V., Bernauer, T., Kalbhenn, A., Spilker, G., 2012. Climate variability, economic growth, and civil conflict. Journal of Peace Research 49 (1), 113-127. 
Kuepie, M., Sougane, A., 2014. Participation citoyenne au Mali : entre mobilisation associative et engagement politique. Lien social et Politiques (71), 197-215, [In French].

La Porta, R., Lopez-de-Silanes, F., Shleifer, A., Vishny, R., 1999. The quality of government. The Journal of Law, Economics, and Organization 15 (1), 222-279.

Leclerc-Olive, M., 2017. Anthropologie des prédations foncières. Entreprises minières et pouvoirs locaux. Éditions des Archives contemporaines, Paris, [In French].

Lin, N., 1999. Building a Network Theory of Social Capital. Connections 22 (1), $28-51$.

Miguel, E., Roland, G., 2011. The long-run impact of bombing Vietnam. Journal of Development Economics 96 (1), 1-15.

Miguel, E., Satyanath, S., Sergenti, E., 2004. Economic Shocks and Civil Conflict: An Instrumental Variables Approach. Journal of Political Economy 112 (4), 725-753.

Narayan, D., Pritchett, L., 1999. Cents and Sociability: Household Income and Social Capital in Rural Tanzania. Economic Development and Cultural Change 47 (4), 871-897.

Nunn, N., Qian, N., 2014. US Food Aid and Civil Conflict. American Economic Review 104 (6), $1630-66$.

Nunn, N., Wantchekon, L., 2011. The Slave Trade and the Origins of Mistrust in Africa. American Economic Review 101 (7), $3221-3252$.

Olson, M., 1982. The Rise and Decline of Nations. Yale University Press, New Haven, CT.

Oster, E., 2019. Unobservable Selection and Coefficient Stability: Theory and Evidence. Journal of Business \& Economic Statistics 37 (2), 187-204.

Paxton, P., Ressler, R., 2017. Trust and Participation in Associations. In: Uslaner, E. M. (Ed.), The Oxford Handbook of Social and Political Trust. Oxford University Press, Ch. 8, pp. 149-174.

Putnam, R. D., Leonardi, R., Nonetti, R. Y., 1993. Making Democracy Work: Civic Traditions in Modern Italy. Princeton University Press, Princeton, NJ.

Raleigh, C., Linke, A., Hegre, H., Karlsen, J., 2010. Introducing ACLED: An Armed Conflict Location and Event Dataset. Journal of peace research 47 (5), 651-660.

Razafindrakoto, M., Roubaud, F., 2018. Responding to the SDG16 Measurement Challenge: The Governance, Peace and Security Survey Modules in Africa. Global Policy 9 (3), 336-351.

Rohner, D., Thoenig, M., Zilibotti, F., 2013. Seeds of distrust: conflict in Uganda. Journal of Economic Growth 18 (3), $217-252$.

Roy, A., 2005. La société civile dans le débat politique au Mali. Cahiers d'études africaines (178), 573-584, [In French].

Roy, A., 2010. Mali: instrumentalisation de la société civile. Alternatives Sud 17, 111-118, [In French].

Satyanath, S., Voigtländer, N., Voth, H.-J., 2017. Bowling for Fascism: Social Capital and the Rise of the Nazi Party. Journal of Political Economy 125 (2), 478-526.

Sawyer, A., 2005. Social capital, survival strategies, and their potential for post-conflict governance in Liberia. UNU-WIDER, Research Paper No. 2005/15, United Nations University (UNU).

Sønderskov, K. M., 2011. Does Generalized Social Trust Lead to Associational Membership? Unravelling a Bowl of Well-Tossed Spaghetti. European Sociological Review 27 (4), 419-434.

Stock, J. H., Yogo, M., 2005. Testing for Weak Instruments in Linear IV Regression. In: Andrews, D. W. K., Stock, J. H. (Eds.), Identification and Inference for Econometric Models: Essays in Honor of Thomas Rothenberg. Cambridge University Press, Ch. 5, pp. 80-108.

United Nations High Commissioner for Refugees (UNHCR), 2014. UNHCR Position On Returns To Mali - Update I. Available at: http://www.refworld.org/docid/52cc405a4.html [accessed 19 April 2017].

United Nations High Commissioner for Refugees (UNHCR), 2016. Mali Situation: UNHCR Regional Update, December 2015 - February 2016. Available at: http://www.refworld.org/docid/56fcd7094.html [accessed 19 April 2017].

Uphoff, N., Wijayaratna, C., 2000. Demonstrated Benefits from Social Capital: The Productivity of Farmer Organizations in Gal Oya, Sri Lanka. World Development 28 (11), 1875 - 1890.

Voors, M. J., Nillesen, E. E. M., Verwimp, P., Bulte, E. H., Lensink, R., Van Soest, D. P., 2012. Violent Conflict and Behavior: A Field Experiment in Burundi. American Economic Review 102 (2), 941-964.

Woolcock, M., 1998. Social capital and economic development: Toward a theoretical synthesis and policy framework. Theory and Society 27 (2), 151-208.

Woolcock, M., Narayan, D., 2000. Social Capital: Implications for Development Theory, Research, and Policy. World Bank Research Observer 15 (2), 225-249.

Wooldridge, J. M., 2009. Introductory Econometrics: a Modern Approach, 4th Edition. South-Western Cengage Learning, Mason, Ohio. 